\title{
Analysis of $\beta$-Subunit-dependent $\mathrm{GABA}_{\mathrm{A}}$ Receptor Modulation and Behavioral Effects of Valerenic Acid Derivatives $\$$
}

\author{
S. Khom, ${ }^{1}$ J. Hintersteiner, ${ }^{2}$ D. Luger, ${ }^{2}$ M. Haider, G. Pototschnig, M. D. Mihovilovic, \\ C. Schwarzer, ${ }^{1}$ and S. Hering
}

Department of Pharmacology and Toxicology, University of Vienna, Vienna, Austria (S.K., J.H., D.L., S.H.); Institute of Applied Synthetic Chemistry, TU Wien, Vienna, Austria (M.H., G.P., M.D.M.); and Department of Pharmacology, Medical University of Innsbruck, Innsbruck, Austria (C.S.)

Received February 20, 2016; accepted April 6, 2016

\begin{abstract}
Valerenic acid (VA) - a $\beta 2 / 3$-selective GABA type A $\left(\mathrm{GABA}_{\mathrm{A}}\right)$ receptor modulator-displays anxiolytic and anticonvulsive effects in mice devoid of sedation, making VA an interesting drug candidate. Here we analyzed $\beta$-subunit-dependent enhancement of GABA-induced chloride currents ( ( $_{\text {GABA }}$ ) by a library of VA derivatives and studied their effects on pentylenetetrazole (PTZ)induced seizure threshold and locomotion. Compound-induced $I_{\text {GABA }}$ enhancement was determined in oocytes expressing $\alpha 1 \beta 1 \gamma 2 \mathrm{~S}, \alpha 1 \beta 2 \gamma 2 \mathrm{~S}$, or $\alpha 1 \beta 3 \gamma 2 \mathrm{~S}$ receptors. Effects on seizure threshold and locomotion were studied using C57BL/6N mice and compared with saline-treated controls. $\beta 2 / 3$-selective VA derivatives such as VA-amide (VA-A) modulating $\alpha 1 \beta 3 \gamma 2 S$ (VA-A: $\mathrm{E}_{\max }=972 \pm 69 \%, n=6, P<0.05$ ) and $\alpha 1 \beta 2 \gamma 2 \mathrm{~S}$ receptors $\left(\mathrm{E}_{\max }=1119 \pm 72 \%, n=6, P<0.05\right)$ more efficaciously than VA $\left(\alpha 1 \beta 3 \gamma 2 \mathrm{~S}: \mathrm{VA}: \mathrm{E}_{\max }=632 \pm 88 \%, n=9\right.$ versus $\alpha 1 \beta 2 \gamma 2 \mathrm{~S}$ : VA: $\mathrm{E}_{\max }=721 \pm 68 \%, n=6$ ) displayed significantly more pronounced seizure threshold elevation than VA (saline control:
\end{abstract}

$40.4 \pm 1.4 \mathrm{mg} / \mathrm{kg} \mathrm{PTZ}$ versus VA $10 \mathrm{mg} / \mathrm{kg}: 49.0 \pm 1.8 \mathrm{mg} / \mathrm{kg}$ PTZ versus VA-A $3 \mathrm{mg} / \mathrm{kg}: 57.9 \pm 1.9 \mathrm{mg} / \mathrm{kg} \mathrm{PTZ,} P<0.05)$. Similarly, VA's methylamide (VA-MA) enhancing I IABA through $\beta 3$-containing receptors more efficaciously than VA $\left(E_{\max }=\right.$ $1043 \pm 57 \%, P<0.01, n=6$ ) displayed stronger anticonvulsive effects. Increased potency of I GABA enhancement and anticonvulsive effects at lower doses compared with VA were observed for VA-tetrazole $\left(\alpha 1 \beta 3 \gamma 2 \mathrm{~S}\right.$ : VA-TET: $\mathrm{EC}_{50}=6.0 \pm 1.0 \mu \mathrm{M}, P<$ 0.05; VA-TET: $0.3 \mathrm{mg} / \mathrm{kg}: 47.3 \pm 0.5 \mathrm{mg} / \mathrm{kg}$ PTZ versus VA: $10 \mathrm{mg} / \mathrm{kg}: 49.0 \pm 1.8 \mathrm{mg} / \mathrm{kg}$ PTZ, $P<0.05)$. At higher doses ( $\geq 10 \mathrm{mg} / \mathrm{kg}$ ), VA-A, VA-MA, and VA-TET reduced locomotion. In contrast, unselective VA derivatives induced anticonvulsive effects only at high doses $(30 \mathrm{mg} / \mathrm{kg})$ or did not display any behavioral effects. Our data indicate that the $\beta 2 / 3$-selective compounds VA-A, VA-MA, and VA-TET induce anticonvulsive effects at low doses $(\leq 10 \mathrm{mg} / \mathrm{kg})$, whereas impairment of locomotion was observed at doses $\geq 10 \mathrm{mg} / \mathrm{kg}$.

\section{Introduction}

Interaction of GABA with GABA type $\mathrm{A}\left(\mathrm{GABA}_{\mathrm{A}}\right)$ receptors enables fast inhibitory neurotransmission in the mammalian brain (Barnard et al., 1998; Olsen and Sieghart, 2008; Sigel and Steinmann, 2012). Like other members of the family of pentameric ligand-gated ion channels, $\mathrm{GABA}_{\mathrm{A}}$ receptors are constituted by pseudosymmetrical assembly of five identical or homologous subunits forming a chloride-conducting ion

The authors thank the Austrian Science Fund for financial support (P-22395, TRP-107; D.L., J.H., and G.P. are fellows of the FWF-funded doctoral program "Ion channels and transporters as drug targets" W-1232). M.H. is supported by the Initiativkolleg Functional Molecules IK 1041-N. Synthesis of VA-derivatives was supported by FFG Innovationsscheck 839639 .

${ }^{1}$ S.K. and C.S. contributed equally to this work as co-corresponding authors.

${ }^{2}$ J.H. and D.L. contributed equally to this work.

dx.doi.org/10.1124/jpet.116.232983.

S This article has supplemental material available at jpet.aspetjournals.org.
(Miller and Aricescu, 2014). The human genome comprises genes encoding for 19 different $\mathrm{GABA}_{\mathrm{A}}$ receptor subunits $[\alpha 1-6, \beta 1-3, \gamma 1-3, \delta, \varepsilon, \rho 1-3, \pi$, and $\theta$ (Simon et al., 2004)], theoretically allowing the formation of multiple $\mathrm{GABA}_{\mathrm{A}}$ receptor subtypes. The receptor's subunit composition determines its pharmacological properties including agonist sensitivity as well as its sensitivity for drugs (Barnard et al., 1998; Sigel and Steinmann, 2012). In addition, the highly specific cellular and subcellular distribution of $\mathrm{GABA}_{\mathrm{A}}$ receptor subunits/subtypes (Pirker et al., 2000; Schwarzer et al., 2001; Olsen and Sieghart, 2008) and in particular the assignment of therapeutic effects of commonly applied GABA $A_{A}$ receptor modulators such as benzodiazepines (e.g., Möhler et al., 2001; Rudolph et al., 2001; Rudolph and Knoflach, 2011; Gallos et al., 2012, 2015; Rudolph and Möhler, 2014) or anesthetics (Jurd et al., 2003) to single GABA $\mathrm{A}_{\mathrm{A}}$ receptor subunits raises the possibility of developing drugs selectively

ABBREVIATIONS: ANOVA, analysis of variance; DMSO, dimethylsulfoxide; GABA $A$, GABA type A; $I_{G A B A}$, GABA-induced chloride currents; PTZ, pentylenetetrazole; VA, valerenic acid; VA-A, VA-amide [(E)-3-((4S,7R,7aR)-3,7-dimethyl-2,4,5,6,7,7a-hexahydro-1H-inden-4-yl)-2-methylacrylamide]; VA-CN, VA-nitrile [(E)-3-((4S,7R,7aR)-3,7-dimethyl-2,4,5,6,7,7a-hexahydro-1H-inden-4-yl)-2-methylacrylonitrile]; VA-DEA, VA-diethylamide [(E)-3-((4S,7R, 7aR)-3,7-dimethyl-2,4,5,6,7,7a-hexahydro-1H-inden-4-yl)- $N, N$-diethyl-2-methylacrylamide)]; VA-DMA, VA-dimethylamide [\{E)-3-((4S,7R,7aR)-3,7-dimethyl2,4,5,6,7,7a-hexahydro-1H-inden-4-yl)-N,N,2-trimethylacrylamide)]; VA-EA, VA-ethylamide [(E)-3-((4S,7R,7aR)-3,7-dimethyl-2,4,5,6,7,7a-hexahydro-1Hinden-4-yl)- $N$-ethyl-2-methylacrylamide)]; VA-MA, VA-methylamide $[(E)-3-((4 S, 7 R, 7 a R)-3,7-d i m e t h y l-2,4,5,6,7,7 a-h e x a h y d r o-1 H$-inden-4-yl)- $N$, 2-dimethylacrylamide]; VA-TET, VA-tetrazole; [5-((E)-1-((4S, 7R,7aR)-3,7-dimethyl-2,4,5,6,7,7a-hexahydro-1H-inden-4-yl)prop-1-en-2-yl)-1H-tetrazole)]. 
targeting specific brain circuits. Such subunit-selective $\mathrm{GABA}_{\mathrm{A}}$ receptor modulators are predicted to display the desired therapeutic effects with reduced side effects.

Valerenic acid (VA), a sesquiterpenoid compound found in common Valerian, selectively modulates $\gamma$-aminobutyric acid type $\mathrm{A}\left(\mathrm{GABA}_{\mathrm{A}}\right)$ receptors containing $\beta 2$ - or $\beta 3$-subunits, while displaying only negligible effects on $\mathrm{GABA}_{\mathrm{A}}$ receptors incorporating $\beta 1$-subunits (Khom et al., 2007; Benke et al., 2009). In vivo, VAinduces anxiolytic (Benke et al., 2009; Khom et al., 2010; Hintersteiner et al., 2014) and anticonvulsive (Hintersteiner et al., 2014) effects. Most notably, VA does not significantly reduce locomotor activity even at high doses (Khom et al., 2010).

These findings combined with a promising pharmacokinetic profile (Sampath et al., 2012) make VA an interesting drug candidate. Previously, we reported more pronounced anxiolytic and/or anticonvulsive effects by selected VA amide (Khom et al., 2010) and ester derivatives (Hintersteiner et al., 2014). In contrast to VA ester derivatives that are significantly less active in vitro and thus might act as prodrugs (Hintersteiner et al., 2014), both VA amide derivatives (Khom et al., 2010; Kopp et al., 2010) as well as VA's nitrile and tetrazole analogs (Kopp et al., 2010) efficaciously enhance GABA-induced chloride currents $\left(\mathrm{I}_{\mathrm{GABA}}\right)$ through receptors composed of $\alpha 1 \beta 3$ subunits (Khom et al., 2010) or $\alpha 1 \beta 2 \gamma 2 \mathrm{~S}$ (Kopp et al., 2010) expressed in Xenopus oocytes.

Therefore, to evaluate the potential of VA derivatives as scaffold for the development of novel anticonvulsants, we extended these previous studies by determining $\beta$-subunit dependency of $\mathrm{I}_{\mathrm{GABA}}$ modulation by a small focused library of VA derivatives in oocytes expressing $\alpha 1 \beta 1 \gamma 2 \mathrm{~S}, \alpha 1 \beta 2 \gamma 2 \mathrm{~S}$, or $\alpha 1 \beta 3 \gamma 2 \mathrm{~S}$ receptors followed by an in vivo investigation of their effects on pentylenetetrazole (PTZ)-induced seizure threshold and locomotor activity in male C57BL/6N mice.

Our study shows that VA's amide (VA-A) and methylamide (VA-MA) derivatives, respectively, modulating $\alpha 1 \beta 3 \gamma 2 \mathrm{~S}$ $\mathrm{GABA}_{\mathrm{A}}$ receptors more efficaciously than VA displayed also significantly more pronounced elevation of PTZ-induced seizure threshold. In addition, VA's tetrazole derivative (VA-TET), an efficacious VA derivative already reported in a preceding study by Kopp et al. (2010) modulating $\alpha 1 \beta 3 \gamma 2$ S receptors more potently than VA, displayed anticonvulsive effects at lower doses than the VA. In contrast, unselective VA derivatives such VA-ethylamide (VA-EA) or VA-diethylamide (VA-DEA) displayed anticonvulsive effects only at high doses $(30 \mathrm{mg} / \mathrm{kg})$ or did not show any effects on either PTZ-induced seizure threshold or locomotion (VA-dimethylamide, VA-DEA).

\section{Materials and Methods}

Animals and Animal Welfare. All experiments involving animals were approved by the Austrian Animal Experimentation Ethics Board in compliance with the European convention for the protection of vertebrate animals used for experimental and other scientific purposes ETS no.: 123, which is in line with the EU Directive 2010/63/ EU (GZ 66.006/0019-C/GT/2007, GZ 66.006/0008-II/10b/2008 and GZ $66.006 / 0009-\mathrm{II} / 10 \mathrm{~b} / 2010$ ). Every effort was taken to minimize the number of animals used.

Female Xenopus laevis frogs were purchased from NASCO (Fort Atkinson, WI) and kept in groups in temperature-controlled, continuous-flow water tanks $\left(20 \pm 1^{\circ} \mathrm{C}\right)$. Male mice $(\mathrm{C} 57 \mathrm{BL} / 6 \mathrm{~N})$ were obtained from Charles River Laboratories (Sulzfeld, Germany). Mice were group housed (maximum 5 mice per type IIL cage) with free access to food and water. At least 24 hours before the commencement of experiments, they were transferred to the testing facility, continuing ad libitum access to food and water.

The temperature in the holding (for mice and frogs) and testing facilities was fixed to $22 \pm 2^{\circ} \mathrm{C}$; the humidity ranged between 40 and $60 \%$; a 12-hour light-dark cycle was in operation (lights on from 0700 to 1900 ).

Chemicals. All chemicals used in this study were obtained from Sigma Aldrich (Vienna, Austria) except where stated otherwise. VA was purchased from HWI Pharma Solutions (Rülzheim, Germany). VA derivatives (structural formulae are depicted in Fig. 1) were synthesized as previously described: description of the syntheses of VA-A [(E)-3-((4S,7R,7aR)-3,7-dimethyl-2,4,5,6,7,7a-hexahydro- $1 H$-inden4-yl)-2-methylacrylamide)], VA-MA [(E)-3-((4S,7R,7aR)-3,7-dimethyl2,4,5,6,7,7a-hexahydro- $1 H$-inden-4-yl)- $N, 2$-dimethylacrylamide)], VA-DMA [(E)-3-((4S,7R,7aR)-3,7-dimethyl-2,4,5,6,7,7a-hexahydro- $1 H$-inden4-yl)- $N, N, 2$-trimethylacrylamide)], VA-EA [(E)-3-((4S,7R,7aR)-3,7-dimethyl-2,4,5,6,7,7a-hexahydro-1 $H$-inden-4-yl)- $N$-ethyl-2-methylacrylamide)], VA-DEA [(E)-3-((4S,7R,7aR)-3,7-dimethyl-2,4,5,6,7,7a-hexahydro- $1 H$-inden4-yl)- $N, N$-diethyl-2-methylacrylamide)] can be found in (Khom et al., 2010) and for VA-TET [5-( $(E)-1-((4 \mathrm{~S}, 7 \mathrm{R}, 7 \mathrm{aR})-3,7-$ dimethyl-2,4,5,6,7,7a-hexahydro$1 H$-inden-4-yl)prop-1-en-2-yl)-1 $H$-tetrazole)] and VA-CN [(E)-3-((4S,7R,7aR)3,7-dimethyl-2,4,5,6,7,7a-hexahydro- $1 H$-inden-4-yl)-2-methylacrylonitrile)], see Kopp et al., 2010. Stock solutions ( $100 \mathrm{mM}$ for in vitro experiments and $1 \mathrm{mg} / 10 \mu \mathrm{l}$ for in vivo experiments, respectively) were prepared in $100 \%$ dimethylsulfoxide (DMSO). VA and its derivatives were used up to a concentration of $500 \mu \mathrm{M}$ in in vitro experiments. Equal amounts of DMSO were present in control and compound-containing solutions. The maximum DMSO concentration in the bath $(0.5 \%)$ did not affect $\mathrm{I}_{\mathrm{GABA}}$. For in vivo experiments, working concentrations were adjusted by dilution with $0.9 \%$ sodium chloride; the final concentration of DMSO was fixed to $10 \%$ including control solutions. To enhance solubility of the compound, Tween 80 (3\% final concentration) was added to all solutions. $\mathrm{pH}$ was adjusted to 7.2-7.4 with $1 \mathrm{M}$ sodium hydroxide. All solutions were freshly prepared every day before experiments.

Expression and Functional Characterization of GABA $_{A}$ Receptors. Preparation of stage V-VI oocytes from Xenopus laevis (NASCO, Fort Atkinson), synthesis of capped off run-off poly $\left(\mathrm{A}^{+}\right)$rat cRNA transcripts from linearized cDNA templates ( $\mathrm{pCMV}$ vector) was performed as described elsewhere (Khom et al., 2006). Briefly, female Xenopus laevis were anesthetized by exposing them for $15 \mathrm{~min}$ to a $0.2 \%$ solution of MS-222 (methane sulfonate salt of 3-aminobenzoic acid ethyl ester) before surgically removing parts of the ovaries. Follicle membranes from isolated oocytes were enzymatically digested with $2 \mathrm{mg} / \mathrm{ml}$ collagenase (Type 1A). Oocytes were stored at $18^{\circ} \mathrm{C}$ in ND96 solution (Methfessel et al., 1986). After isolation, oocytes were injected with about $10-50 \mathrm{nl}$ of nuclease-free water containing the different rat cRNAs (100-2000 ng/ $\mu \mathrm{l} /$ subunit). For expression of $\alpha 1 \beta 3 \gamma 2 \mathrm{~S}$ and $\alpha 1 \beta 2 \gamma 2 \mathrm{~S}$ receptors, respectively, cRNAs were mixed in a ratio of 1:1:10 (Boileau et al., 2002); to avoid formation of homooligomeric $\beta 1$-receptors in the case of $\alpha 1 \beta 1 \gamma 2 \mathrm{~S}$, a ratio of $3: 1$ : 10 was used (Krishek et al., 1996). Electrophysiological experiments were done using the two-microelectrode voltage-clamp technique at a holding potential of $-70 \mathrm{mV}$, making use of a TURBO TEC 01C amplifier (npi electronic, Tamm, Germany) and an Axon Digidata 1322A interface (Molecular Devices, Sunnyvale, CA). Data acquisition was carried out using pCLAMP v.9.2 (Molecular Devices). The bath solution contained $90 \mathrm{mM} \mathrm{NaCl}, 1 \mathrm{mM} \mathrm{KCl}, 1 \mathrm{mM} \mathrm{MgCl}_{2}, 1 \mathrm{mM} \mathrm{CaCl}_{2}$, and $5 \mathrm{mM}$ HEPES (pH 7.4). Microelectrodes were filled with $2 \mathrm{M} \mathrm{KCl}$ and had resistances between 1 and $3 \mathrm{M} \Omega$.

Perfusion System. GABA and drugs were applied by means of a fast perfusion system; drug or control solutions were applied by means of a TECAN Miniprep 60 permitting automation of the experiments [(Baburin et al., 2006) ScreeningTool, npi electronic]. To elicit $\mathrm{I}_{\mathrm{GABA}}$, the chamber was perfused with $120 \mu \mathrm{l}$ of GABA-containing solution at a volume rate between 300 and $1000 \mu \mathrm{l} / \mathrm{s}$. The $\mathrm{I}_{\mathrm{GABA}}$ rise time ranged between 100 and $250 \mathrm{~ms}$ (Khom et al., 2006). To account for possible slow recovery from increasing levels of desensitization in the presence of high compound concentrations, the duration of washout periods was 
<smiles>CC1=C2[C@@H](/C=C(\C)C(=O)O)CC[C@@H](C)[C@H]2CC1</smiles>

VA<smiles>[R]N([R])C(=O)/C(C)=C/[C@H]1CC[C@H](C)[C@@H]2CCC(C)=C21</smiles><smiles>CC1=C2C(/C=C(\C)c3nnn[nH]3)CC[C@H](C)[C@H]2CC1</smiles>

VA-TET<smiles>CC1=C2[C@@H](/C=C(\C)C#N)CC[C@H](C)[C@H]2CC1</smiles>

VA-CN
Fig. 1. VA and VA derivatives. Structural formulae of studied valerenic acid (VA) and VA derivatives are illustrated. extended stepwise, i.e., $1 \mathrm{~min}\left(\mathrm{GABA} \mathrm{EC}_{3-7}\right)$ to $1.5 \mathrm{~min}$ (coapplication of $\mathrm{GABA} \mathrm{EC}_{3-7}$ in the presence $\leq 1 \mu \mathrm{M}$ compound) to $2.5 \mathrm{~min}$ (coapplication of GABA EC $\mathrm{EC}_{3-7}$ in the presence of $\leq 10 \mu \mathrm{M}$ compound) to $5 \mathrm{~min}$ (coapplication of GABA $\mathrm{EC}_{3-7}$ and $\leq 100 \mu \mathrm{M}$ compound) to 15 min (GABA EC $\mathrm{EC}_{3-7}$ in the presence of $300-500 \mu \mathrm{M}$ compound). Oocytes with maximal current amplitudes $>5 \mu \mathrm{A}$ were discarded to exclude voltage-clamp errors.

Analyzing Concentration-response Curves. Enhancement of chloride currents $\left(\mathrm{I}_{\mathrm{GABA}}\right)$ by VA and VA derivatives was measured at a GABA concentration eliciting between 3 and $7 \%$ of the maximal current amplitude $\left(\mathrm{EC}_{3-7}\right)$. The $\mathrm{EC}_{3-7}$ was determined at the beginning of the experiment for each oocyte by application of $1 \mathrm{mM}$ GABA followed by submaximal GABA concentrations. $\mathrm{I}_{\mathrm{GABA}}$ enhancement was defined as $\left.\left.\left[\mathrm{I}_{(\mathrm{GABA}+\mathrm{Comp}}\right) \mathrm{I}_{\mathrm{GABA}}\right)-1\right]$, where $\mathrm{I}_{(\mathrm{GABA}+\mathrm{Comp})}$ is the current response in the presence of compound and $\mathrm{I}_{\mathrm{GABA}}$ is the control GABA current. Concentration-response curves were generated, and the data were fitted by nonlinear regression analysis using Origin software (OriginLab Corporation, Northampton, MA). Data were fitted to the following equation:

$$
\mathrm{Y}=\min +(\max -\min )^{*} \mathrm{x}^{\mathrm{nH}} /\left(\mathrm{k}^{\mathrm{nH}}+\mathrm{x}^{\mathrm{nH}}\right) .
$$

In this equation, $\mathrm{k}$ corresponds to the $\mathrm{EC}_{50}$ value, $\mathrm{x}$ values are logs of concentration, and $n_{H}$ stands for the Hill coefficient. Each data point represents the mean \pm S.E.M. from $\geq 3$ oocytes and $\geq 2$ oocyte batches.

In Vivo Characterization of VA Derivatives. Only male C57BL/6N mice (age 3-6 months) were used in the tests described below. Intraperitoneal injection of control or compound-containing solutions was done $30 \mathrm{~min}$ before the test. Indicated doses in the Results and Discussion represent milligrams per kilogram body weight.

Seizure Threshold. Seizure threshold was determined by pentylenetetrazole (PTZ) tail-vein infusion on freely moving animals at a rate of $100 \mu \mathrm{l} / \mathrm{min}(10 \mathrm{mg} / \mathrm{ml} \mathrm{PTZ}$ in saline, $\mathrm{pH}=7.4)$. Infusion was stopped when animals displayed generalized clonic seizures. Animals were immediately killed by cervical displacement after onset of seizures. The seizure threshold dose was calculated from the infused dose in relation to body weight $(\mathrm{mg} / \mathrm{kg})$.

Open-field Test. Exploration of a novel environment was tested over $10 \mathrm{~min}$ in a $50 \times 50 \mathrm{~cm}$ box built from gray PVC equipped with infrared beams. Illumination intensity was set to 150 lux in the center. Animals' motor activity was analyzed using ActiMot-2 equipment and software (TSE-systems, Bad Homburg, Germany).

Statistical Analysis. Statistical significance was calculated using one-way analysis of variance (ANOVA) followed by a post hoc mean comparison with Bonferroni (OriginLab Corporation or GraphPad, La Jolla, CA). $P$ values of $<0.05$ were accepted as statistically significant. All data are given as mean \pm S.E.M.

\section{Results}

Determination of $\beta$-Subunit Dependency of $\mathbf{I}_{\mathrm{GABA}}$ Modulation by Valerenic Acid and VA Derivatives. GABA receptors composed of $\alpha 1 \beta 1 \gamma 2 \mathrm{~S}, \alpha 1 \beta 2 \gamma 2 \mathrm{~S}$, or $\alpha 1 \beta 3 \gamma 2 \mathrm{~S}$ subunits were expressed in Xenopus laevis oocytes, and modulation of GABA-induced chloride currents $\left(\mathrm{I}_{\mathrm{GABA}}, \mathrm{GABA} \mathrm{EC}_{3-7}\right)$ by VA and seven carboxyl-group modified derivatives was analyzed by means of the two-microelectrode voltage-clamp technique (for structural formulae of investigated VA derivatives, see Fig. 1). Amidation of VA (VA-amide, VA-A) resulted in significantly stronger $\mathrm{I}_{\mathrm{GABA}}$ enhancement of both $\alpha 1 \beta 3 \gamma 2 \mathrm{~S}$ (VA-A: $\mathrm{E}_{\max }=972 \pm 69 \%, n=6$ versus VA: $\left.\mathrm{E}_{\max }=632 \pm 88 \%, n=9, P<0.01\right)$ and $\alpha 1 \beta 2 \gamma 2 \mathrm{~S}$ receptors (VA-A: $\mathrm{E}_{\max }=1119 \pm 72 \%, n=6$ versus VA: $\mathrm{E}_{\max }=$ $721 \pm 68 \%, n=5, P<0.05$, compare Fig. 2, A and C). Subsequent monomethylation of VA-A (VA-mono-methylamide, VA-MA) also significantly increased $\mathrm{I}_{\mathrm{GABA}}$ enhancement of $\alpha 1 \beta 3 \gamma 2 \mathrm{~S}$ receptors (VA-MA: $\mathrm{E}_{\max }=1043 \pm 57 \%, n=5, P<0.01$, Fig. 2E) compared with VA; in addition, a strong trend toward more pronounced $\mathrm{I}_{\mathrm{GABA}}$ enhancement of $\alpha 1 \beta 2 \gamma 2 \mathrm{~S}$ channels by VA-MA was 
A

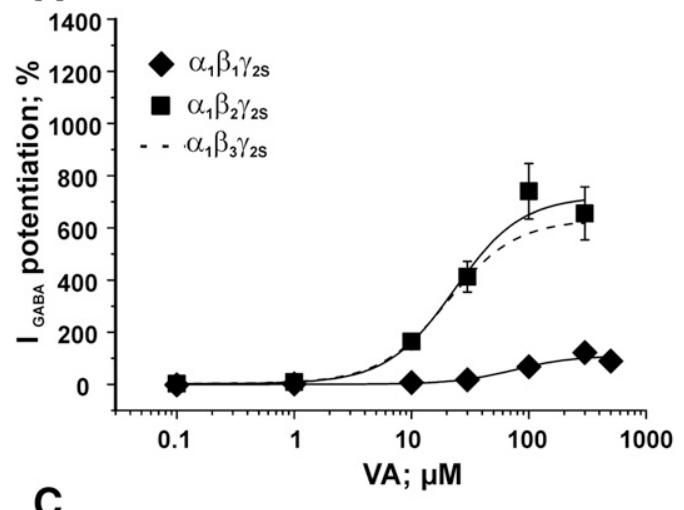

C
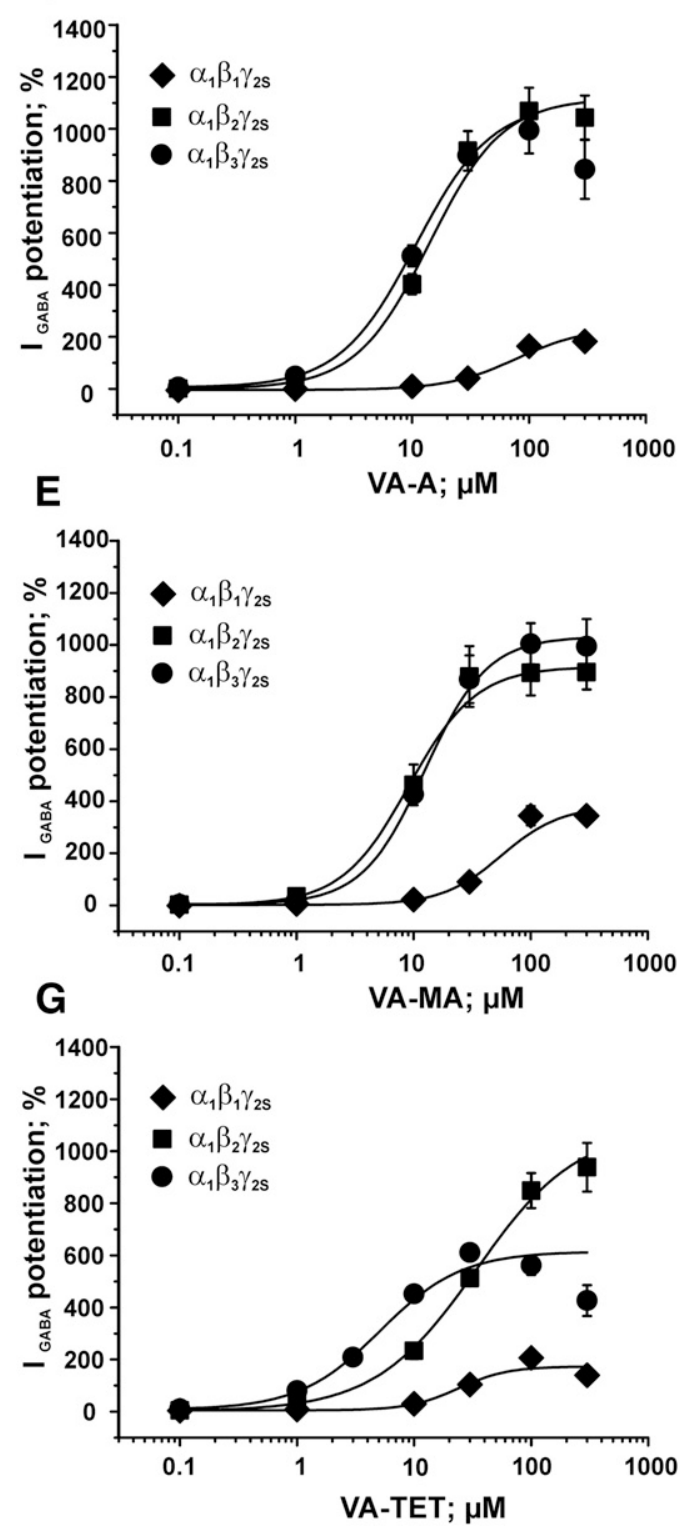

B

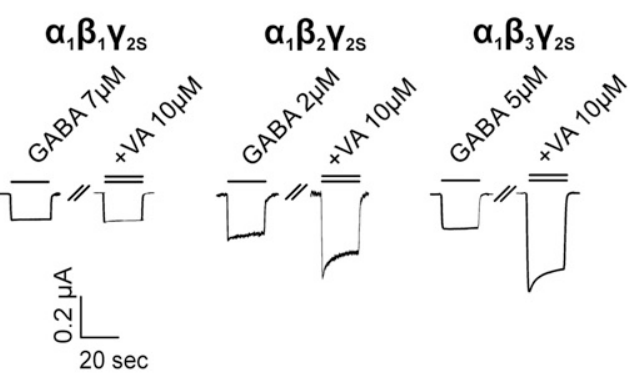

D
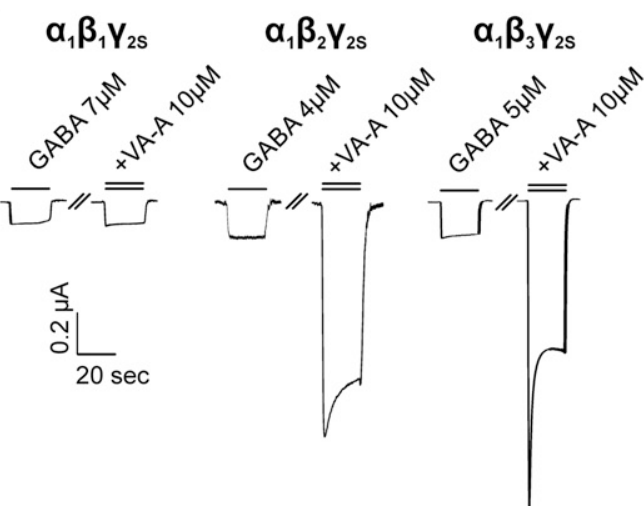

F

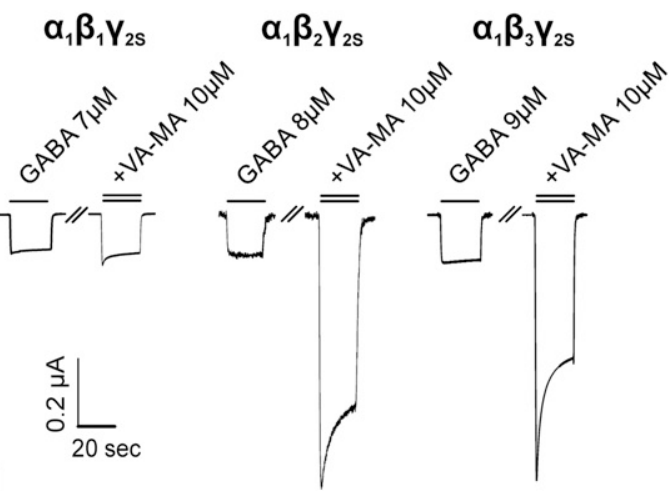

H
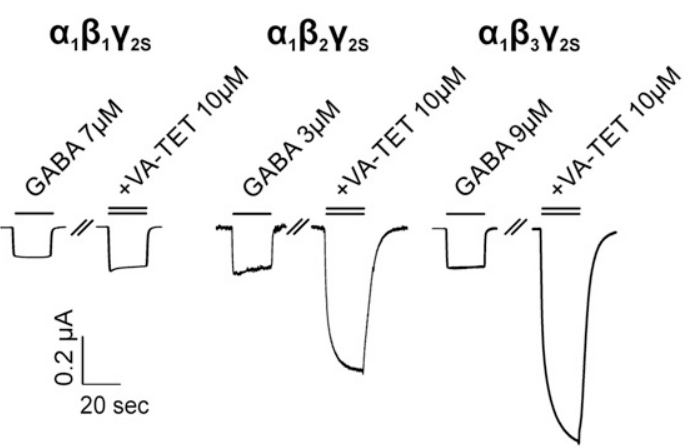

Fig. 2. $\beta$-Subunit-dependent $I_{\mathrm{GABA}}$ enhancement by VA and VA derivatives. Concentration-dependent modulation of GABA receptors composed of $\alpha 1 \beta 3 \gamma 2 \mathrm{~S}$ (dashed line), $\alpha 1 \beta 2 \gamma 2 \mathrm{~S}(\mathbf{\square})$, and $\alpha 1 \beta 1 \gamma 2 \mathrm{~S}$ ( ) subunits by (A) VA (data for enhancement of $\alpha 1 \beta 3 \gamma 2 \mathrm{~S}$ receptors taken from (Luger et al., 2015), (C) VA-A, (E) VA-MA, and (G) VA-TET. Data were fitted by nonlinear regression as described in Materials and Methods. Maximal potentiation of $\mathrm{I}_{\mathrm{GABA}}$ $\left(\mathrm{E}_{\max }\right), \mathrm{EC}_{50}$ values, Hill-coefficients $\left(\mathrm{n}_{\mathrm{H}}\right)$ and number of experiments for each compound on $\alpha 1 \beta 1 \gamma 2 \mathrm{~S}, \alpha 1 \beta 2 \gamma 2 \mathrm{~S}$ and $\alpha 1 \beta 3 \gamma 2 \mathrm{~S}$ receptors are summarized in Table 1. Each data point represents a mean \pm S.E.M from at least 3 different oocytes from 2 different frog batches. $\mathrm{I}_{\mathrm{GABA}}$ potentiation at $300 \mu \mathrm{M}$ ( $\alpha 1 \beta 3 \gamma 2 \mathrm{~S}$ receptors) for VA and VA-A, respectively, was excluded from the fit. Typical traces for the enhancement of GABA-induced chloride currents ( $\mathrm{I}_{\mathrm{GABA}}, \mathrm{EC}_{3-7}$, single bar) by $10 \mu \mathrm{M}$ of (B) VA, (D) VA-A, (F) VA-MA, and (H) VA-TET (double bar; indicating coapplication of GABA and compound) at the indicated $\mathrm{GABA}_{\mathrm{A}}$ receptor subtype are illustrated. 
TABLE 1

Summary of pharmacological parameters of $\mathrm{I}_{\mathrm{GABA}}$ enhancement through $\alpha_{1} \beta_{1} \gamma_{2 \mathrm{~S}}, \alpha_{1} \beta_{2} \gamma_{2 \mathrm{~S}}$, and $\alpha_{1} \beta_{3} \gamma_{2 \mathrm{~S}}$ receptors including maximal I $\mathrm{I}_{\mathrm{GABA}}$ enhancement $\left(\mathrm{E}_{\max }\right)$, half-maximal effective concentrations $\left(\mathrm{EC}_{50}\right)$, Hillcoefficients $\left(\mathrm{n}_{\mathrm{H}}\right)$, and number of experiments for each compound at the tested subunit combinations

Data for $\mathrm{I}_{\mathrm{GABA}}$ enhancement of $\alpha 1 \beta 3 \gamma 2 \mathrm{~S}$ receptors by VA at GABA $\mathrm{EC}_{3-7}$ concentrations taken from Luger et al. (2015).

\begin{tabular}{|c|c|c|c|c|}
\hline & $\mathrm{E}_{\max }(\%)$ & $\mathrm{EC}_{50}()$ & $\mathrm{n}_{\mathrm{H}}$ & $n$ \\
\hline & $\%$ & $\mu M$ & & \\
\hline \multicolumn{5}{|l|}{$\alpha 1 \beta 1 \gamma 2 \mathrm{~S}$} \\
\hline VA & $111 \pm 16$ & $74.4 \pm 19.3$ & $1.6 \pm 0.5$ & 8 \\
\hline VA-A & $218 \pm 78$ & $66.6 \pm 34.6$ & $1.8 \pm 0.6$ & 6 \\
\hline VA-MA & $387 \pm 56$ & $58.1 \pm 16.5$ & $1.6 \pm 0.3$ & 5 \\
\hline VA-DMA & $305 \pm 67$ & $52.5 \pm 20.1$ & $1.7 \pm 0.5$ & 6 \\
\hline VA-EA & $458 \pm 124$ & $51.4 \pm 19.8$ & $1.6 \pm 0.3$ & 5 \\
\hline VA-DEA & $318 \pm 84$ & $97.2 \pm 33.8$ & $1.8 \pm 0.3$ & 7 \\
\hline VA-CN & $55 \pm 14$ & $73.0 \pm 38.7$ & $1.7 \pm 0.7$ & 7 \\
\hline VA-TET & $176 \pm 43$ & $23.5 \pm 10.9$ & $1.8 \pm 0.6$ & 7 \\
\hline \multicolumn{5}{|l|}{$\alpha 1 \beta 2 \gamma 2 \mathrm{~S}$} \\
\hline VA & $721 \pm 68$ & $23.1 \pm 4.2$ & $1.4 \pm 0.2$ & 5 \\
\hline VA-A & $1119 \pm 72$ & $14.0 \pm 2.2$ & $1.4 \pm 0.2$ & 6 \\
\hline VA-MA & $917 \pm 36$ & $9.1 \pm 1.4$ & $1.5 \pm 0.1$ & 3 \\
\hline VA-DMA & $594 \pm 36$ & $63.9 \pm 23.7$ & $1.3 \pm 0.2$ & 5 \\
\hline VA-EA & $554 \pm 49$ & $11.0 \pm 3.6$ & $1.6 \pm 0.3$ & 3 \\
\hline VA-DEA & $573 \pm 33$ & $54.4 \pm 11.1$ & $1.6 \pm 0.3$ & 5 \\
\hline VA-CN & $765 \pm 117$ & $56.5 \pm 13.3$ & $2.5 \pm 0.7$ & 4 \\
\hline VA-TET & $1091 \pm 87$ & $34.1 \pm 6.3$ & $1.0 \pm 0.1$ & 5 \\
\hline \multicolumn{5}{|l|}{$\alpha 1 \beta 3 \gamma 2 \mathrm{~S}$} \\
\hline VA & $632 \pm 88$ & $20.2 \pm 5.2$ & $1.5 \pm 0.3$ & 9 \\
\hline VA-A & $972 \pm 69$ & $7.5 \pm 1.8$ & $1.5 \pm 0.2$ & 6 \\
\hline VA-MA & $1043 \pm 57$ & $12.7 \pm 0.9$ & $1.5 \pm 0.1$ & 6 \\
\hline VA-DMA & $415 \pm 61$ & $48.0 \pm 16.0$ & $1.4 \pm 0.2$ & 6 \\
\hline VA-EA & $677 \pm 64$ & $27.2 \pm 6.7$ & $1.3 \pm 0.2$ & 12 \\
\hline VA-DEA & $374 \pm 102$ & $80.8 \pm 31.3$ & $1.9 \pm 0.5$ & 5 \\
\hline VA-CN & $522 \pm 114$ & $42.4 \pm 15.8$ & $2.1 \pm 0.8$ & 7 \\
\hline VA-TET & $668 \pm 57$ & $6.0 \pm 1.0$ & $1.1 \pm 0.1$ & 8 \\
\hline
\end{tabular}

observed; however, this effect did not reach statistical significance (VA-MA: $\mathrm{E}_{\max }=917 \pm 36 \%, n=3, P>0.05$, Fig. $2 \mathrm{E}$ ). Modulation of $\mathrm{I}_{\mathrm{GABA}}$ through $\beta 1$-containing receptors by VA-A and VA-MA did not significantly differ, although slightly enhanced, from $\mathrm{I}_{\mathrm{GABA}}$ enhancement by VA $\left[\alpha 1 \beta 1 \gamma 2 \mathrm{~S}\right.$ : VA: $\mathrm{E}_{\max }=111 \pm 16 \%, n=8$ versus VA-A: $\mathrm{E}_{\max }=218 \pm 78 \%, n=6$; VA-MA: $\mathrm{E}_{\max }=387 \pm$ $56 \%, n=5 ; P>0.05$; compare Fig. 2, A, C, and E; see also Table 1, see also (Khom et al., 2010; Kopp et al., 2010) for VA-A enhancement of $\alpha 1 \beta 1-3, \alpha 1 \beta 2 \gamma 2 \mathrm{~S}$, and $\alpha 3 \beta 3 \gamma 2 \mathrm{~S}$ and VA-MA enhancement of $\alpha 1 \beta 3$ and $\alpha 1 \beta 2 \gamma 2$ S receptors].

Replacement of the carboxyl moiety by the bioisosteric tetrazole group (VA-TET) significantly increased efficacy on $\alpha 1 \beta 2 \gamma 2 \mathrm{~S}\left(\mathrm{E}_{\max }=1091 \pm 87 \%, n=5, P<0.05\right.$, Fig. $\left.2 \mathrm{G}\right)$ receptors, although with a slightly reduced potency compared with VA, whereas efficacy of $\mathrm{I}_{\mathrm{GABA}}$ enhancement on $\alpha 1 \beta 1 \gamma 2 \mathrm{~S}$ $\left(\mathrm{E}_{\max }=176 \pm 43 \%, n=7\right)$ and $\alpha 1 \beta 3 \gamma 2 \mathrm{~S}\left(\mathrm{E}_{\max }=668 \pm 57 \%\right.$, $n=8$; Fig. 2G) receptors did not differ from that of the parent compound. However, most remarkably, VA-TET displayed an approximately threefold increased potency on $\beta 3$-containing receptors compared with $\mathrm{VA}\left(\mathrm{VA}: \mathrm{EC}_{50}=20.2 \pm 5.2 \mu \mathrm{M} ; n=9\right.$ versus VA-TET: $\mathrm{EC}_{50}=6.0 \pm 1.0 \mu \mathrm{M} ; n=8$; see Fig. 2 for representative current traces for $\beta$-subunit-dependent $\mathrm{I}_{\mathrm{GABA}}$ enhancement by (Fig. 2B) VA, (Fig. 2D) VA-A, (Fig. 2F) VA-MA, and (Fig. 2H) VA-TET; data for $\mathrm{I}_{\mathrm{GABA}}$ enhancement of $\mathrm{GABA}_{\mathrm{A}}$ channels composed of $\alpha 1 \beta 3 \gamma 2 \mathrm{~S}$ subunits by VA are taken from Luger et al. (2015); see also the effect of VA-TET applied at low GABA concentrations $\left(\mathrm{EC}_{1-4}\right)$ in Kopp et al. (2010).

Similarly, substituting VA's carboxyl group by a nitrile (VA nitrile, VA-CN) did not affect $\beta 2 / 3$-subunit-selective $\mathrm{I}_{\mathrm{GABA}}$ potentiation: $\mathrm{I}_{\mathrm{GABA}}$ enhancement by VA-CN through $\alpha 1 \beta 1 \gamma 2 \mathrm{~S}$
$\left(\mathrm{E}_{\max }=55 \pm 14 \%, n=7\right), \alpha 1 \beta 2 \gamma 2 \mathrm{~S}\left(\mathrm{E}_{\max }=765 \pm 117 \%, n=\right.$ 4 ), and $\alpha 1 \beta 3 \gamma 2 \mathrm{~S}\left(\mathrm{E}_{\max }=522 \pm 114 \%, n=7\right)$ channels, respectively, was similar to that of $\mathrm{VA}$; however, a trend toward slightly decreased potency on $\beta 2$ - and $\beta 3$-subunitcontaining receptors was observed [see Fig. 3A; see also Kopp et al. (2010) for $\mathrm{I}_{\mathrm{GABA}}$ enhancement through $\alpha 1 \beta 2 \gamma 2 \mathrm{~S}$ channels by VA-CN at GABA $\mathrm{EC}_{1-4}$ concentrations].

In contrast, introducing bulkier residues such as monoethylamide (VA-EA), dimethylamide (VA-DMA), or diethylamide (VA-DEA) significantly elevated efficacy on $\beta_{1}$-containing receptors compared with $\mathrm{VA}$ (VA-EA: $\mathrm{E}_{\max }=458 \pm 124 \%$, $n=5$, Fig. $3 \mathrm{~B}$; VA-DMA: $\mathrm{E}_{\max }=305 \pm 67 \%, n=6$, Fig. $3 \mathrm{C}$; VA-DEA: $\mathrm{E}_{\max }=318 \pm 84 \%, n=7$, Fig. $\left.3 \mathrm{D} ; P>0.05\right)$, whereas the estimated efficacies on $\beta 2$ - and $\beta 3$-containing receptors were comparable to VA, indicating a loss of subunit selectivity (Figs. 3B-D). Data for maximal $\mathrm{I}_{\mathrm{GABA}}$ enhancement $\left(\mathrm{E}_{\max }, \%\right)$, $\mathrm{EC}_{50}(\mu \mathrm{M})$, Hill-coefficients $\left(\mathrm{n}_{\mathrm{H}}\right)$, and number of experiments (n) for all receptor subunit compositions tested are summarized in Table 1.

Effects of VA and VA Derivatives on PentylenetetrazoleInduced Seizure Threshold. We recently reported that the elevation of PTZ-induced seizure threshold by VA (3 $\mathrm{mg} / \mathrm{kg}$ body weight) is most pronounced $30 \mathrm{~min}$ after application (Hintersteiner et al., 2014). In the present study, dose-dependent effects of VA on seizure threshold were determined. As depicted in Fig. 4A, VA did not alter seizure threshold at doses $<3 \mathrm{mg} / \mathrm{kg}$ body weight; in contrast, pronounced seizure threshold elevation was observed after application of VA at a dose of 3 or $10 \mathrm{mg} / \mathrm{kg}$ body weight [control: $40.4 \pm 1.4 \mathrm{mg} / \mathrm{kg}$ PTZ, $n=6$ versus VA $3 \mathrm{mg} / \mathrm{kg}: 47.7 \pm$ $1.4 \mathrm{mg} / \mathrm{kg}$ PTZ, $n=4, P<0.01$ and VA $10 \mathrm{mg} / \mathrm{kg}: 49.0 \pm 1.8 \mathrm{mg} / \mathrm{kg}$ PTZ, $n=4 ; P<0.05$, respectively; data for seizure threshold elevation by VA at a dose of $3 \mathrm{mg} / \mathrm{kg}$ body weight are taken from Hintersteiner et al. (2014)]. Seizure threshold of animals treated with VA at a dose of $30 \mathrm{mg} / \mathrm{kg}$ body weight did not differ significantly from diluent-treated control animals (30 mg/kg VA: $43.4 \pm 1.8 \mathrm{mg} / \mathrm{kg}$ PTZ, $n=3, P>0.05$; Fig. $4 \mathrm{~A}$ ). Compared with VA, VA-A exerted significantly stronger anticonvulsive activity at doses $\geq 3 \mathrm{mg} / \mathrm{kg}$ (see Fig. 4B, VA-A $3 \mathrm{mg} / \mathrm{kg}: 57.9 \pm 1.9 \mathrm{mg} / \mathrm{kg}$ PTZ, $n=4$; VA-A $10 \mathrm{mg} / \mathrm{kg}: 55.4 \pm 0.7 \mathrm{mg} / \mathrm{kg} \mathrm{PTZ,} n=4, P<0.001$ ). Like VA, VA-A also displayed a trend toward reduced activity at higher doses $(30 \mathrm{mg} / \mathrm{kg})$; however, in contrast to VA, it still retained its anticonvulsive potential (Fig. 4B, VA-A $30 \mathrm{mg} / \mathrm{kg}$ : $50.6 \pm 2.2 \mathrm{mg} / \mathrm{kg}$ PTZ, $n=3, P<0.01$ ).

A similar (but left-shifted) bell-shaped dose-response curve on PTZ-induced seizure threshold was observed for VA-TET; at a dose of $0.3 \mathrm{mg} / \mathrm{kg}$ bodyweight (Fig. 4C: VA-TET $0.3 \mathrm{mg} / \mathrm{kg}$ : $47.3 \pm 0.5 \mathrm{mg} / \mathrm{kg}$ PTZ, $n=5, P<0.05$ ) VA-TET's anticonvulsive activity was comparable to that of VA at 10-fold higher doses $(3 \mathrm{mg} / \mathrm{kg})$, indicating a significantly increased potency. However, VA-TET lost its anticonvulsive properties at doses $\geq 1 \mathrm{mg} / \mathrm{kg}$. The methylated VA-A derivative (VA-MA) induced the most pronounced increase in seizure threshold of all tested compounds; first significant effects were observed at a dose of $10 \mathrm{mg} / \mathrm{kg}$ (Fig. 4D: VA-MA $10 \mathrm{mg} / \mathrm{kg}: 50.4 \pm 1.4 \mathrm{mg} / \mathrm{kg}$ PTZ, $n=$ $4, P<0.001)$. In contrast to VA, VA-A, and VA-TET, application of higher doses (i.e., $30 \mathrm{mg} / \mathrm{kg}$ ) VA-MA resulted in an even further elevated seizure threshold (VA-MA 30 $\mathrm{mg} / \mathrm{kg}: 63.6 \pm 2.5 \mathrm{mg} / \mathrm{kg} \mathrm{PTZ}, n=3, P<0.001$ ).

As shown in Fig. 4, F, G, and H, higher doses of VA-EA, VA-DEA, and VA-CN were required for seizure threshold elevation similar to that of VA (compare VA $3 \mathrm{mg} / \mathrm{kg}: 47.7 \pm 1.4 \mathrm{mg} / \mathrm{kg}$ PTZ, $n=4$, Fig. 4 A versus VA-EA $30 \mathrm{mg} / \mathrm{kg}: 55.6 \pm 0.4 \mathrm{mg} / \mathrm{kg}$ 
A

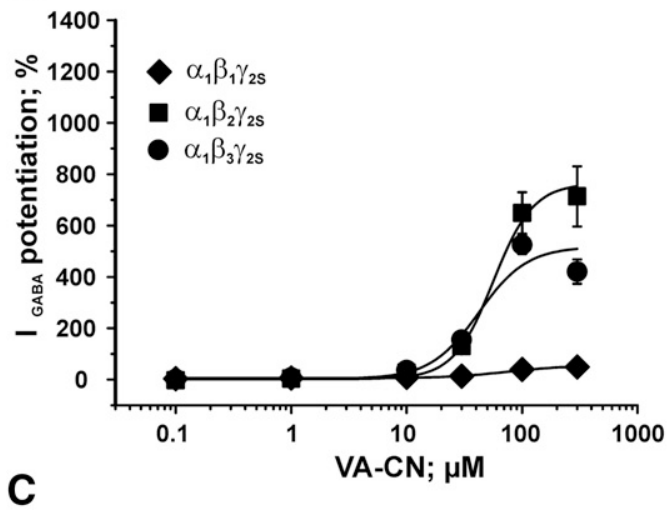

C

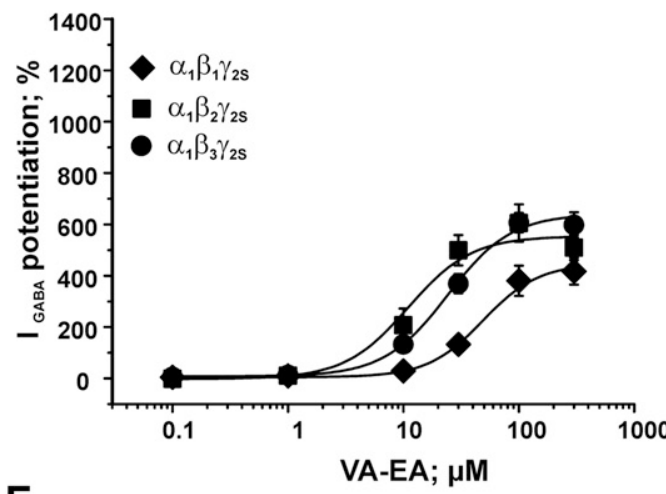

E

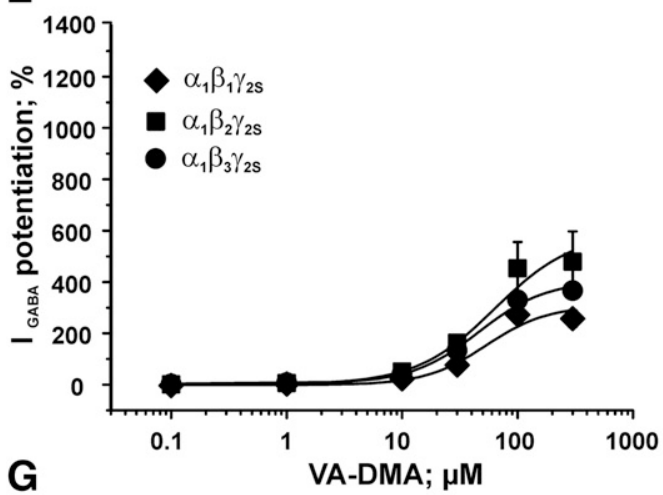

G

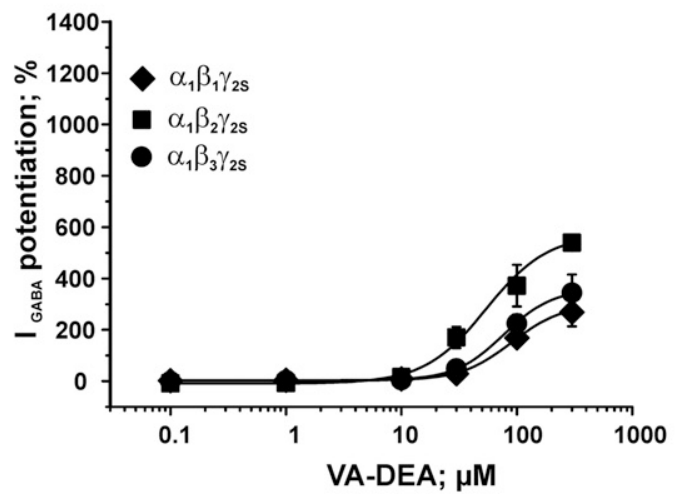

B
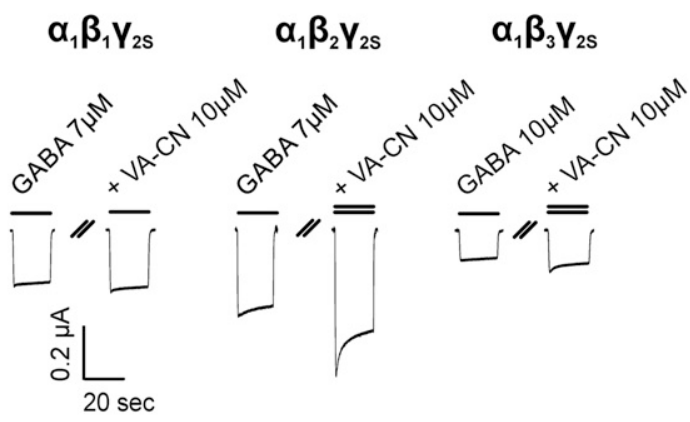

D
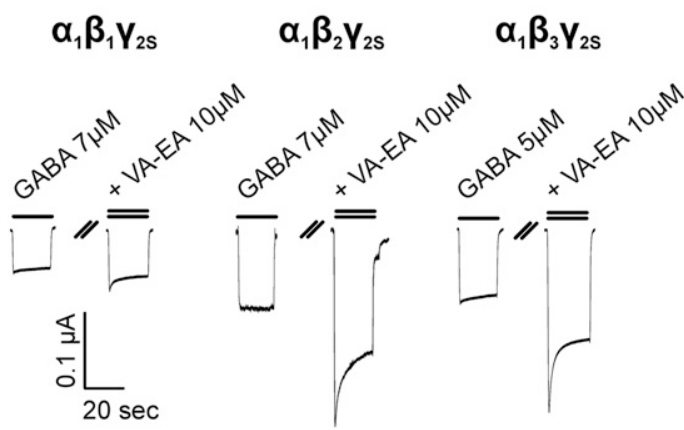

F
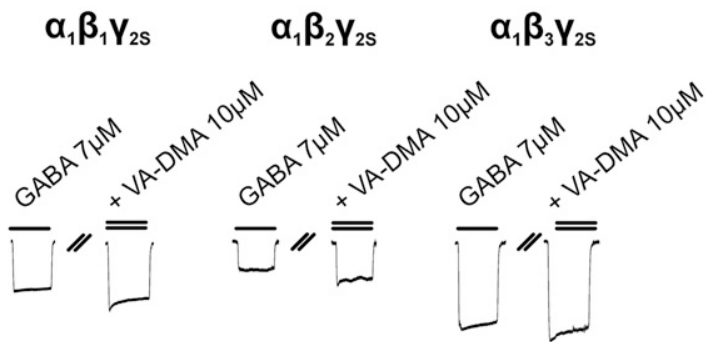

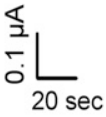

H

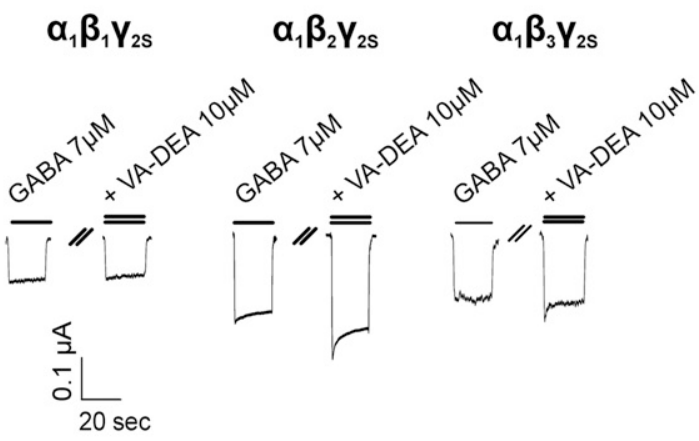

Fig. 3. $\beta$-Subunit-dependent $\mathrm{I}_{\mathrm{GABA}}$ modulation by VA derivatives. Concentration-response curves for the $\mathrm{I}_{\mathrm{GABA}}$ enhancement through $(\bullet) \alpha 1 \beta 3 \gamma 2 \mathrm{~S}$, $(\boldsymbol{\square})$ $\alpha 1 \beta 2 \gamma 2 \mathrm{~S}$, and ()$\alpha 1 \beta 1 \gamma 2 \mathrm{~S}$ channels by VA derivatives (A) VA-CN, (C) VA-EA, (E) VA-DMA, and (G) VA-DEA. Data were fitted by nonlinear regression as described in Materials and Methods. Maximal potentiation of $\mathrm{I}_{\mathrm{GABA}}\left(\mathrm{E}_{\mathrm{max}}\right), \mathrm{EC}_{50}$ values, Hill-coefficients $\left(\mathrm{n}_{\mathrm{H}}\right)$, and number of experiments for each compound on $\alpha 1 \beta 1 \gamma 2 \mathrm{~S}, \alpha 1 \beta 2 \gamma 2 \mathrm{~S}$, and $\alpha 1 \beta 3 \gamma 2 \mathrm{~S}$ receptors are summarized in Table 1. Each data point represents a mean \pm S.E.M. from at least 3 different oocytes from 2 different frog batches. Typical current traces for the enhancement of GABA-induced chloride currents $\left(\mathrm{I}_{\mathrm{GABA}}, \mathrm{EC}_{3-7}\right.$, single bar by $10 \mu \mathrm{M}$ of (B) VA-CN, (D) VA-EA, (F) VA-DMA, and (H) VA-DEA (double bar; indicating coapplication of GABA and compound) at the indicated GABA receptor subtype are illustrated. 
A
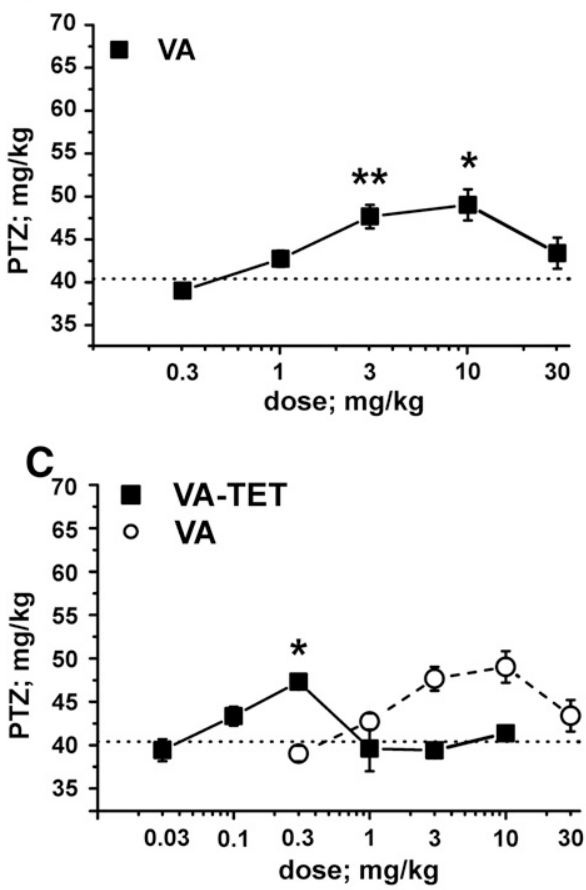

$E$

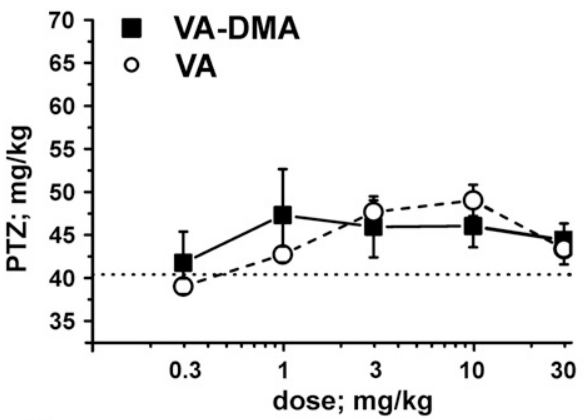

G

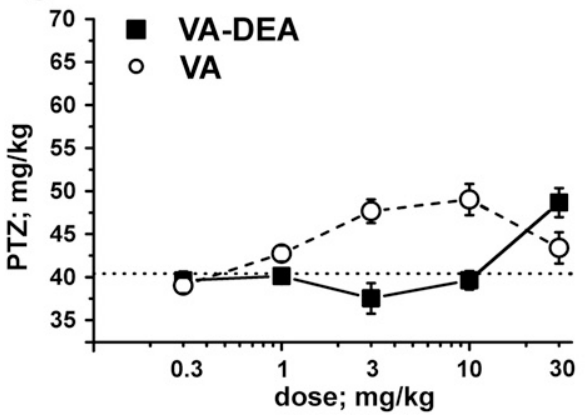

B

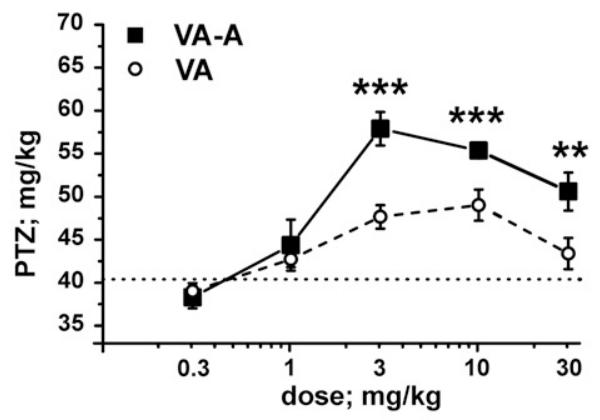

D

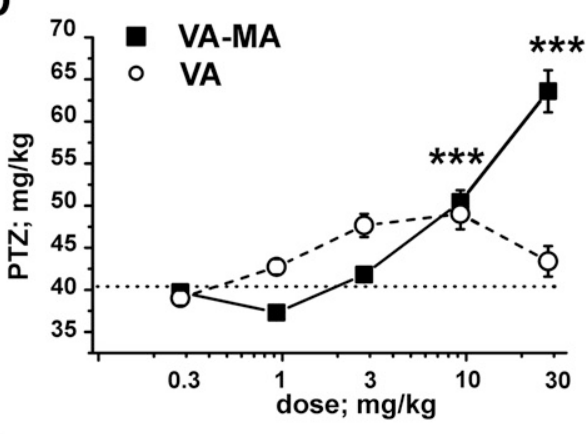

$\mathbf{F}$

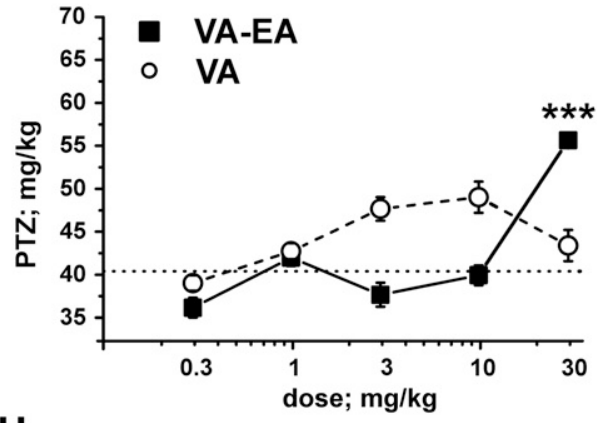

H

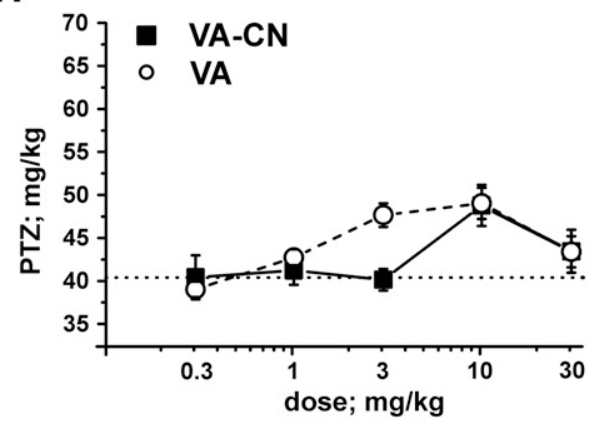

Fig. 4. Anticonvulsive effects of VA and VA derivatives. Elevation of seizure threshold upon tail-vein infusion of PTZ 30 min after intraperitoneal application of (A) VA is illustrated. The dotted line represents the averaged seizure threshold of saline-treated control animals. Effect on PTZ-induced seizure threshold 30 min after intraperitoneal application by the VA derivatives (B) VA-A, (C) VA-TET, (D) VA-MA, (E) VA-DMA, (F) VA-EA, (G) VA-DEA, and (H) VA-CN is compared with VA (dashed line, $\bigcirc$ ) and control animals (dotted line). Each data point represents a mean \pm S.E.M from at least 3 mice. Statistical significance $(P$ values $<0.05$ were accepted as significant; $* P<0.05$, ** $P<0.01$, and $* * * P<$ 0.001 ) against VA was calculated by oneway ANOVA followed by a Bonferroni post hoc mean comparison.
PTZ, $n=4$, Fig. 4F versus VA-DEA: $30 \mathrm{mg} / \mathrm{kg}: 48.7 \pm 1.7 \mathrm{mg} / \mathrm{kg}$ PTZ, $n=3$, Fig. 4G versus VA-CN 10 mg/kg: $51.1 \pm 0.6 \mathrm{mg} / \mathrm{kg}$ PTZ, $n=3$, Fig. $4 \mathrm{H})$.

Seizure threshold of mice treated with VA-DMA (Fig. 4E) did not significantly differ at any tested dose from diluenttreated control littermates.

Effects of VA and Derivatives on Locomotion in the Open Field Test. As illustrated in Fig. 5A, locomotor activity of VA-treated mice did not differ significantly from control animals at any tested dose in the open field test (control: 38.3 $\pm 1.5 \mathrm{~m}, n=25$ versus VA $1 \mathrm{mg} / \mathrm{kg}: 34.9 \pm 1.3 \mathrm{~m}, n=12$ versus
VA $3 \mathrm{mg} / \mathrm{kg}: 38.7 \pm 2.1 \mathrm{~m}, n=16$ versus VA $10 \mathrm{mg} / \mathrm{kg}: 38.0 \pm$ $1.4 \mathrm{~m}, n=16$ versus VA $30 \mathrm{mg} / \mathrm{kg}: 37.6 \pm 2.5 \mathrm{~m}, n=16$ ).

Application of VA derivative VA-A at doses of 1 and $3 \mathrm{mg} / \mathrm{kg}$, respectively, did also not affect the total distance covered compared with control littermates; however, reduced locomotor activity in the open-field test was measured after application of VA-A at doses $\geq 10 \mathrm{mg} / \mathrm{kg}$ (control: $38.3 \pm 1.5 \mathrm{~m}, n=25$ versus VA-A $10 \mathrm{mg} / \mathrm{kg}: 29.9 \pm 2.6 \mathrm{~m}, n=11, P<0.05$ versus VA-A $30 \mathrm{mg} / \mathrm{kg}$ : $23.5 \pm 2.2 \mathrm{~m}, n=18, P<0.001$; see Fig. $5 \mathrm{~B})$.

Like VA-A, derivatives VA-TET (Fig. 5C), VA-MA (Fig. 5D), and VA-CN (Fig. 5E) did not affect locomotor activity at low 
A

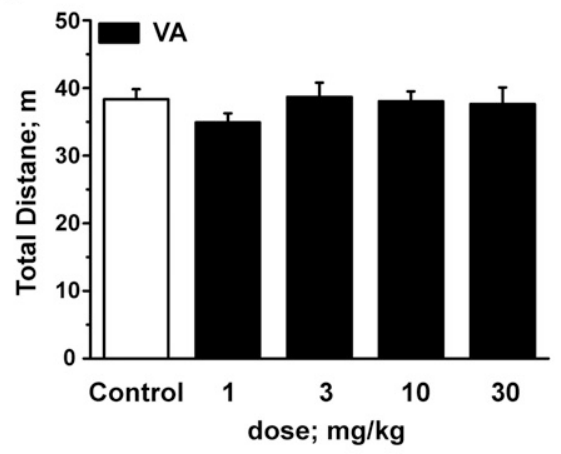

C

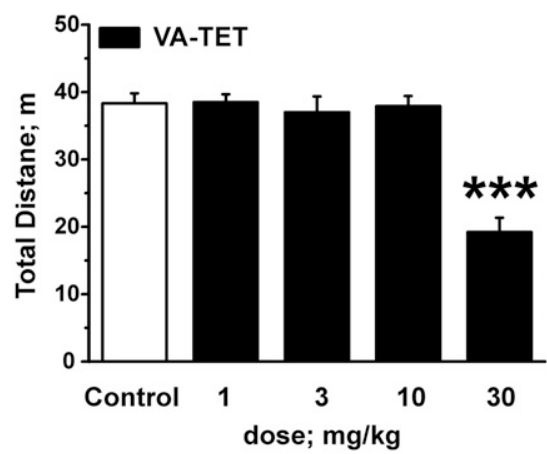

E

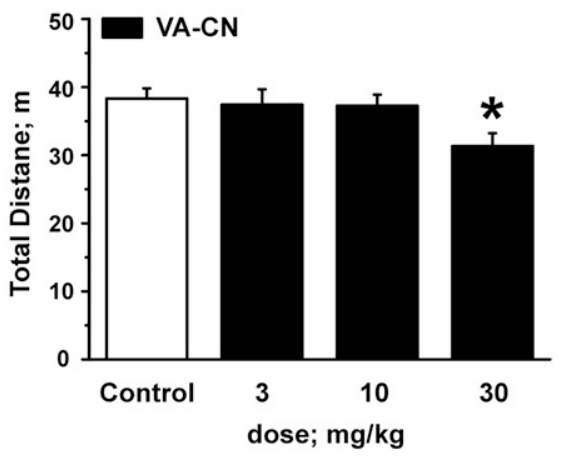

G

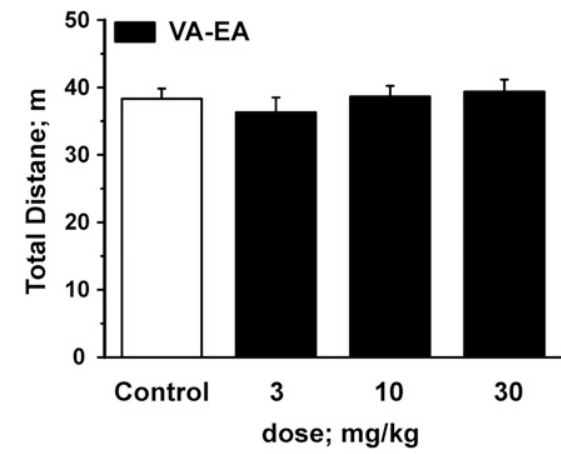

B

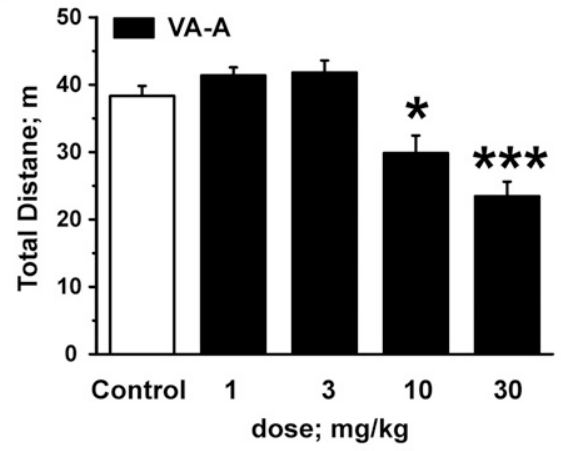

D

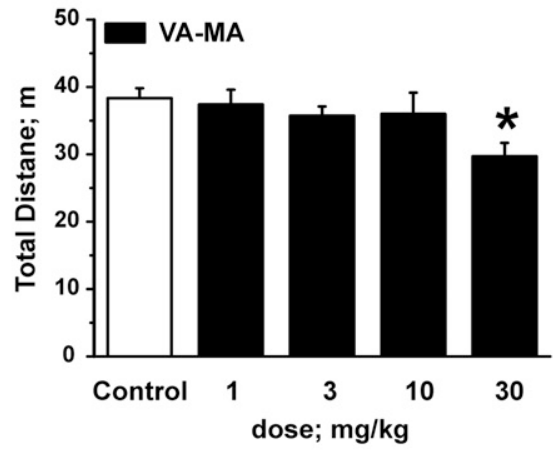

$\mathbf{F}$

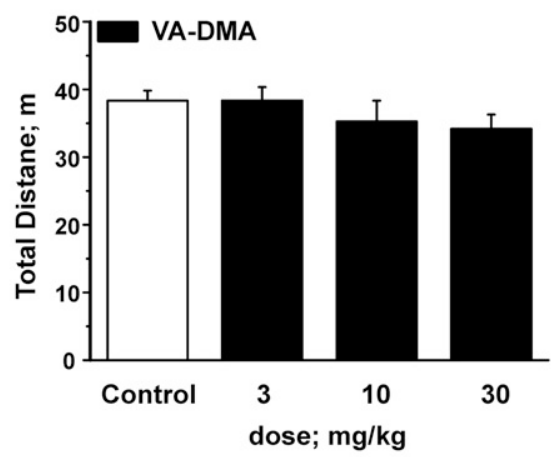

H

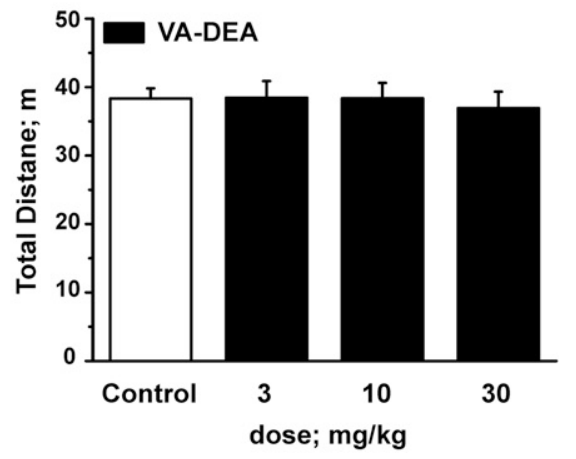

Fig. 5. Effects on locomotion by VA and VA derivatives in the open-field test $(\mathrm{OF})$ test. Black bars indicate the total distance covered in the OF test 30 minutes after intraperitoneal application of (A) VA, (B) VA-A, (C) VA-TET, (D) VA-MA, (E) VA-CN, (F) VA-DMA, (G) VA-EA, and $(\mathrm{H})$ (VA-DEA) at the indicated doses compared with saline-treated control animals (white bars in all panels). Each bar represents a mean \pm S.E.M. from at least 10 different mice. Statistical significance $(P$ values $<0.05$ were accepted as significant; $* P<0.05$ and $* * * P<$ 0.001 ) against saline-treated control animals was calculated by one-way ANOVA followed by a Bonferroni post hoc mean comparison. doses ( $\leq 10 \mathrm{mg} / \mathrm{kg}$ ); however, at higher doses reduced ambulation was observed for these compounds (control: $38.3 \pm$ $1.5 \mathrm{~m}, n=25$ versus VA-TET $30 \mathrm{mg} / \mathrm{kg}: 19.2 \pm 2.1 \mathrm{~m}, n=$ $13, P<0.001$ versus VA-MA $30 \mathrm{mg} / \mathrm{kg}: 29.7 \pm 2.0 \mathrm{~m}, n=12$, $P<0.01$ versus VA-CN $30 \mathrm{mg} / \mathrm{kg}: 31.5 \pm 1.5 \mathrm{~m}, n=14, P<0.05$ ).
Finally, analysis of total distance did not reveal any significantly different behavior of animals treated with any dose of the $\beta$-subunit-unselective VA derivatives VA-DMA (Fig. 5F), VA-EA (Fig. 5G), and VA-DEA (Fig. 5H) or diluenttreated control animals. 


\section{Discussion}

Subunit-selective $\mathrm{GABA}_{\mathrm{A}}$ receptor modulators represent interesting lead structures for drug development. The natural compound VA selectively modulates $\mathrm{GABA}_{\mathrm{A}}$ receptors containing either $\beta 2$ - or $\beta 3$-subunits, with only residual modulatory activity on $\mathrm{GABA}_{\mathrm{A}}$ receptors incorporating $\beta 1$-subunits at high concentrations (Khom et al., 2007; Benke et al., 2009). As opposed to benzodiazepines, VA and also its derivatives do not interact with the benzodiazepine binding site [i.e., $\mathrm{I}_{\mathrm{GABA}}$ enhancement by VA and VA derivatives does not require the presence of a $\gamma 2 \mathrm{~S}$-subunit and VA's modulatory action cannot be blocked by the benzodiazepine site antagonist flumazenil (Khom et al., 2007, 2010)]. This selectivity profile combined with pronounced anticonvulsive effects (Hintersteiner et al., 2014) accompanied by anxiolytic activity (Khom et al., 2010; Hintersteiner et al., 2014) and devoid of significant impairment of locomotor activity suggesting lack of sedative side effects makes VA and potentially also its derivatives promising drug candidates.

Previously, we and others have reported more efficacious and/or potent modulation of $\mathrm{GABA}_{\mathrm{A}}$ receptors expressed in Xenopus oocytes by carboxyl-modified VA derivatives (Khom et al., 2010; Kopp et al., 2010). Furthermore, more pronounced anxiolytic effects by the amide derivative of VA (VA-A) (Khom et al., 2010) as well as stronger anxiolytic and anticonvulsive effects of VA ester derivatives compared with VA were observed (Hintersteiner et al., 2014).

To further evaluate the potential of VA and carboxylmodified derivatives (for structural formulae, see Fig. 1) as scaffolds for the development of novel anticonvulsants with limited impairment of locomotor activity, we extended previous in vitro studies of these compounds (Khom et al., 2010; Kopp et al., 2010) by determining their $\beta$-subunit dependency of $\mathrm{I}_{\mathrm{GABA}}$ modulation $(\alpha 1 \beta 1 \gamma 2 \mathrm{~S}, \alpha 1 \beta 2 \gamma 2 \mathrm{~S}, \alpha 1 \beta 3 \gamma 2 \mathrm{~S})$ followed by a subsequent analysis of their effects on PTZ-induced seizure threshold and locomotion.

VA Derivatization Has Dual Effects on $\beta$-Subunit Selectivity. An interesting finding of the present study was that VA derivatization had, depending on the substituent introduced, dual effects on $\beta$-subunit selectivity; amidation of VA (VA-A) as well as monomethylation of the amide (VA-MA), respectively, strongly increased efficacy of $\mathrm{I}_{\mathrm{GABA}}$ enhancement of $\beta 2$ - and $\beta 3$-containing receptors compared with VA (compare Fig. 2, A, C, and E), whereas efficacy of $\mathrm{I}_{\mathrm{GABA}}$ enhancement through $\beta 1$-containing receptors did not differ significantly from that of VA, thus boosting $\beta$-subunit selectivity. Replacing the carboxyl-function by a tetrazole group (VA-TET) significantly increased potency of $\mathrm{I}_{\mathrm{GABA}}$ enhancement through $\beta 3$-containing receptors and efficacy of $\mathrm{I}_{\mathrm{GABA}}$ of $\beta 2$-containing receptors, whereas modulation of $\beta 1$-receptors by VA-TET was comparable to that of VA (compare Fig. 2, A and C). Intriguingly, this structural modification (replacement of the carboxyl-group by a tetrazole moiety) altered current kinetics (see Fig. $2 \mathrm{H}$ for typical $\mathrm{I}_{\mathrm{GABA}}$ in the presence of $10 \mu \mathrm{M}$ VA-TET); compared with $\mathrm{I}_{\mathrm{GABA}}$ modulated by any of the other studied VA derivatives (Figs. 2 and 3, right panels), receptor activation in the presence of VA-TET appeared to be slowed (see longer time required to reach peak currents), and, in addition, current desensitization could not be observed even at high drug concentrations. The parent compound VA, at concentrations $\geq 30 \mu \mathrm{M}$, has been reported to directly activate
$\mathrm{GABA}_{\mathrm{A}}$ channels in the absence of GABA (see Khom et al., 2007). Compared with $I_{\mathrm{GABA}}$, both activation and deactivation rates of these VA-induced currents were remarkably slower. We speculate that VA-TET, representing the more potent bioisoster of VA in terms of modulatory activity (see Table 1 and Fig. 2, A and G), might also directly activate the channel like VA at lower concentrations and that the observed kinetics reflect a combination of direct activation and modulatory activity. However, these differences in current kinetics warrant further investigations.

Substituting the carboxyl-group by a nitrile function (VA-CN) resulted in a similar $\beta 2 / 3$-subunit dependency as observed for VA (Fig. 3A). In contrast, introduction of bulkier residues such as dimethylamide (VA-DMA), ethylamide (VA-EA), or diethylamide (VA-DEA) did not alter efficacy or potency of $\mathrm{I}_{\mathrm{GABA}}$ enhancement of $\beta 2$ - or $\beta 3$-containing receptors compared with VA, but these compounds efficaciously modulated $\beta 1$-containing receptors, indicating a loss of $\beta$-subunit selectivity (see Fig. 3, B-D).

Evaluation of Anticonvulsive Effects and Potential Impairment of Locomotor Activity by VA Derivatives. In line with the stronger $\mathrm{I}_{\mathrm{GABA}}$ enhancement by VA-A in vitro, VA-A also induced a more pronounced seizure threshold elevation compared with VA (compare Fig. 4, A, B, and D). However, in contrast to VA that did not affect locomotor activity even at doses up to $30 \mathrm{mg} / \mathrm{kg}$ compared with saline-treated control animals, application of VA-A ( $\geq 10 \mathrm{mg} / \mathrm{kg}$ ) significantly reduced locomotor activity. This finding suggests that VA-A, as opposed to VA, also induces sedative effects (compare Fig. 5, A and B). A similar profile was observed for VA-MA: compared with VA, $\mathrm{I}_{\mathrm{GABA}}$ enhancement of $\beta 3$ - and $\beta 2$-containing receptors in vitro was more pronounced, and stronger anticonvulsive effects were also accompanied by a reduction of locomotor activity at higher doses $(30 \mathrm{mg} / \mathrm{kg})$.VA-TET displaying in vitro significantly more potent $\mathrm{I}_{\mathrm{GABA}}$ enhancement of $\beta 3$-containing receptors (efficacy comparable to VA) and more efficacious $\mathrm{I}_{\mathrm{GABA}}$ enhancement of $\beta 2$-receptors, elevated PTZ-induced seizure threshold at 10-fold lower doses than VA (VA-TET: $0.3 \mathrm{mg} / \mathrm{kg}: 47.3 \pm 0.5 \mathrm{mg} / \mathrm{kg}$ PTZ versus VA $3 \mathrm{mg} / \mathrm{kg}: 47.7 \pm 1.4$ $\mathrm{mg} / \mathrm{kg}$ PTZ (Fig. 4C) but also induced the strongest reduction of locomotor activity of all tested VA derivatives at a dose of 30 $\mathrm{mg} / \mathrm{kg}$ (Fig. $5 \mathrm{C}$ ). These presumably sedative effects by VA-TET were, however, observed at doses more than 100-fold higher than those required for anticonvulsive effects $(0.3 \mathrm{mg} / \mathrm{kg}$; see also Figs. 4C and 5C).

Efficacy and potency of $\mathrm{I}_{\mathrm{GABA}}$ enhancement ( $\left.\alpha 1 \beta 1-3 \gamma 2 \mathrm{~S}\right)$ by the nitrile derivative (VA-CN) did not significantly differ from that of VA. A trend toward-although not reaching statistical significance-reduced potency for $\beta 1$ - and $\beta 3$-containing receptors compared with VA was observed (Fig. 3A). However, higher doses of VA-CN $(10 \mathrm{mg} / \mathrm{kg})$ were required for seizure threshold elevation (Fig. $4 \mathrm{H}$ ) and, as opposed to VA, VA-CN also slightly reduced locomotion at high doses $(30 \mathrm{mg} / \mathrm{kg}$; Fig. $5 \mathrm{E})$.

Unaffected locomotor activity and either no effect on PTZinduced seizure threshold or anticonvulsive effects occurring at rather high doses $(30 \mathrm{mg} / \mathrm{kg})$ were observed for the unselective VA derivatives (i.e., comparable efficacy and potency on $\alpha 1 \beta 1-3 \gamma 2 \mathrm{~S}$ receptors) VA-EA (Figs. $4 \mathrm{~F}$ and $5 \mathrm{G}$ ) and VA-DEA (Figs. $4 \mathrm{G}$ and $5 \mathrm{H}$ ) and VA-DMA (Figs. $4 \mathrm{E}$ and $5 \mathrm{~F}$ ).

These findings, $\beta 2 / 3$-selective VA derivatives displaying anticonvulsive effects at low doses $(\leq 10 \mathrm{mg} / \mathrm{kg})$ and sedative effects at higher doses $(\geq 10 \mathrm{mg} / \mathrm{kg})$ while unselective VA 
derivatives (VA-EA, VA-DEA) are anticonvulsive at higher doses $(30 \mathrm{mg} / \mathrm{kg}$ ) without affecting locomotor activity, prompted us to probe a possible link between $\beta$-subunit selectivity and behavioral effects of this set of VA derivatives. Indeed, plotting maximal seizure threshold elevation (maximal effect or the effect reached at a dose of $30 \mathrm{mg} / \mathrm{kg}$ ) versus the efficacy of $\mathrm{I}_{\mathrm{GABA}}$ enhancement at different subunit compositions in vitro revealed a significant correlation between the compounds' efficacy at $\beta 3$-containing receptors and anticonvulsive effects (for details, see Supplemental Material). Derivatives enhancing $\mathrm{I}_{\mathrm{GABA}}$ at $\beta 3$-containing receptors more efficaciously than VA also displayed stronger protection against PTZinduced seizures $(r=0.8785 ; P<0.01$, see Supplemental Fig. 1S). Conversely, efficacy at neither $\beta 2$ - nor $\beta 1$-containing receptors correlated with the extent of seizure threshold elevation. However, VA derivatives modulating $\beta 2$-containing receptors more efficaciously also induced more pronounced impairment of locomotor activity $(r=-0.9262 ; P<0.001$, Supplemental Fig. 1S), whereas neither efficacy nor potency of $\mathrm{VA}$ and its derivatives on $\beta 1$ - or $\beta 3$-containing receptors apparently correlated with occurring sedation. Therefore, it is tempting to speculate that the motor-impairing effects (probably sedation) of VA derivatives are determined by the interaction with $\beta 2$-containing receptors, whereas their anticonvulsive effects might be mediated by receptors containing $\beta 3$-subunits. This hypothesis would also be in line with previous studies highlighting the role of $\beta 2$-containing receptors in mediating sedative effects of $\mathrm{GABA}_{\mathrm{A}}$ receptor modulators such as loreclezole (Groves et al., 2006), etomidate (Reynolds et al., 2003; Zeller et al., 2005), or even benzodiazepines (Antkowiak, 2015). In contrast, anticonvulsive effects of $\mathrm{GABA}_{\mathrm{A}}$ receptor ligands apparently might result from a broader, less selective $\mathrm{GABA}_{\mathrm{A}}$ receptor modulation including more than a single $\mathrm{GABA}_{\mathrm{A}}$ receptor subtype; Numerous work has shown that anticonvulsive effects of diazepam are only partially blunted in $\alpha 1 \mathrm{H} 101 \mathrm{R}$ mice, indicating that also $\alpha 2$, $\alpha 3$, and/or $\alpha 5$-containing $\mathrm{GABA}_{\mathrm{A}}$ receptors could contribute to anticonvulsive effects in vivo (Rudolph et al., 1999; Löw et al., 2000; Crestani et al., 2002; Fradley et al., 2007). In addition, the $\beta 2 / 3$-selective $\mathrm{GABA}_{\mathrm{A}}$ receptor ligand loreclezole retained, although reduced, seizure-protecting activity in $\beta 2 \mathrm{~N} 265 \mathrm{~S}$ mice, suggesting a complementary role for $\beta 3$-containing receptors in mediating anticonvulsive effects (Groves et al., 2006). Most notably, the expression of $\beta 3$-subunits is particularly high in dendritic regions of the hippocampus and dentate gyrus (Sperk et al., 1997; Miralles et al., 1999; Hörtnagl et al., 2013). Assuming the fundamental role of the hippocampus in seizure activity and epilepsy (Schwartzkroin, 1994; Coulter et al., 2011), amplifying GABAergic neurotransmission in the hippocampus via $\beta 3$-containing receptors might represent an appealing approach to develop novel anticonvulsants with reduced side effects including sedation.

However, it cannot be ruled out that the observed differences in effects on PTZ-induced seizure threshold and locomotion might be also due to distinct pharmacokinetic properties (e.g., tissue distribution, penetration of the bloodbrain barrier, different onset of in vivo effects, etc.). To answer this question warrants further studies. Furthermore, interaction of VA and its derivatives with targets for anticonvulsive acting drugs other than $\mathrm{GABA}_{\mathrm{A}}$ receptors has not been analyzed in the present study. VA was previously reported to bind to $5-\mathrm{HT}_{5 \mathrm{~A}}$-receptors (Dietz et al., 2005) as well as metabotropic group I/II glutamate receptors (Del Valle-Mojica et al., 2011) and to attenuate physical and psychologic stress responses by decreasing the turnover of serotonin to 5hydroxyindoleacetic acid and turnover of norepinephrine to 3-methoxy-4-hydroxyphenylethyleneglycol sulfate in rodent hippocampus and amygdala (Jung et al., 2015). Thus, both anticonvulsive and sedative effects of the studied compounds might also result from interactions of VA and its derivatives with multiple drug targets. Benke et al. (2009) demonstrated, however, that VA's anxiolytic effect in mice is mediated exclusively by interaction with $\beta 3$-subunit-containing GABA $_{\mathrm{A}}$ receptors based on their observation that VA-induced reduction of anxiety-related behavior was completely absent in $\beta 3 \mathrm{~N} 265 \mathrm{M}$ mice, a point mutation well-known to abolish $\mathrm{I}_{\mathrm{GABA}}$ enhancement by VA and other $\beta 2 / 3$-selective $\mathrm{GABA}_{\mathrm{A}}$ receptor modulators (Groves et al., 2006; Benke et al., 2009). In line with this, the efficacy of the derivates on $\mathrm{GABA}_{\mathrm{A}}$ receptors in vitro highly correlates with the strength of anticonvulsive effects in vivo (this study) and supports the hypothesis that these action are likely to be mediated via $\mathrm{GABA}_{\mathrm{A}}$ receptors.

Taken together, our study demonstrates that modifications of VA's carboxyl function can profoundly alter potency, efficacy, and $\beta$-subunit selectivity of VA derivatives; replacing the carboxyl group by a tetrazole (VA-TET; see also Kopp et al., 2010) as well as amidation (unsubstituted or monomethylated amide; Khom et al., 2010; Kopp et al., 2010) significantly increased efficacy and/or potency of $\mathrm{I}_{\mathrm{GABA}}$ enhancement of $\beta 2 / 3$-containing receptors, and, most importantly, enhanced $\beta 2 / 3$-selectivity. In contrast, introduction of bulkier substituents (as ethyl for VA-EA, dimethyl for VA-DMA, or diethyl for VA-DEA) resulted in significantly increased efficacy on $\beta 1$-containing channels and thus abolished $\beta$-subunit selectivity. Increased efficacy and/or potency of $\mathrm{I}_{\mathrm{GABA}}$ enhancement of $\beta 2 / 3$-containing receptors by VA derivatives VA-A, VA-MA, and VA-TET is likely to result in more pronounced anticonvulsive effects at low doses $(\leq 10 \mathrm{mg} / \mathrm{kg})$, whereas sedative effects occur at higher doses ( $\geq 10 \mathrm{mg} / \mathrm{kg}$ ). In contrast, relatively high doses $(30 \mathrm{mg} / \mathrm{kg})$ of unselective VA derivatives were required for anticonvulsive effects. Our data thus suggest that VA and $\beta 2 / 3$-selective VA derivatives represent interesting scaffolds for the development of novel anticonvulsants.

\section{Acknowledgments}

Technical assistance by Lisa Holler, Helga Dobernig, Daniela Hrabak, Maria Magdalena Müllner, and Erwin Kirnbauer are greatly acknowledged.

\section{Authorship Contributions}

Participated in research design: Khom, Schwarzer, and Hering. Conducted experiments: Khom, Hintersteiner, Luger, and Schwarzer. Contributed new reagents or analytical tools: Haider, Pototschnig, and Mihovilovic.

Performed data analysis: Khom, Luger, and Schwarzer.

Wrote or contributed to the writing of the manuscript: Khom, Luger, Schwarzer, Mihovilovic, and Hering.

\section{References}

Antkowiak B (2015) Closing the gap between the molecular and systemic actions of anesthetic agents. Adv Pharmacol 72:229-262.

Baburin I, Beyl S, and Hering S (2006) Automated fast perfusion of Xenopus oocytes for drug screening. Pflugers Arch 453:117-123.

Barnard EA, Skolnick P, Olsen RW, Mohler H, Sieghart W, Biggio G, Braestrup C, Bateson AN, and Langer SZ (1998) International Union of Pharmacology. XV. Subtypes of gamma-aminobutyric acidA receptors: classification on the basis of subunit structure and receptor function. Pharmacol Rev 50: 291-313. 
Benke D, Barberis A, Kopp S, Altmann K-H, Schubiger M, Vogt KE, Rudolph U, and Möhler H (2009) GABA A receptors as in vivo substrate for the anxiolytic action of valerenic acid, a major constituent of valerian root extracts. Neurophar macology 56:174-181.

Boileau AJ, Baur R, Sharkey LM, Sigel E, and Czajkowski C (2002) The relative amount of cRNA coding for gamma2 subunits affects stimulation by benzodiazepines in GABA(A) receptors expressed in Xenopus oocytes. Neuropharmacology 43 695-700.

Coulter DA, Yue C, Ang CW, Weissinger F, Goldberg E, Hsu F-C, Carlson GC, and Takano H (2011) Hippocampal microcircuit dynamics probed using optical imaging approaches. J Physiol 589:1893-1903.

Crestani F, Keist R, Fritschy J-M, Benke D, Vogt K, Prut L, Blüthmann H, Möhler H, and Rudolph U (2002) Trace fear conditioning involves hippocampal alpha5 GABA (A) receptors. Proc Natl Acad Sci USA 99:8980-8985.

Del Valle-Mojica LM, Ayala-Marín YM, Ortiz-Sanchez CM, Torres-Hernández BA Abdalla-Mukhaimer S, and Ortiz JG (2011) Selective interactions of Valeriana officinalis extracts and valerenic acid with $[\mathrm{H}]$ glutamate binding to rat synaptic membranes. Evid Based Complement Alternat Med 2011:403591.

Dietz BM, Mahady GB, Pauli GF, and Farnsworth NR (2005) Valerian extract and valerenic acid are partial agonists of the 5-HT5a receptor in vitro. Brain Res Mol Brain Res 138:191-197.

Fradley RL, Guscott MR, Bull S, Hallett DJ, Goodacre SC, Wafford KA, Garrett EM, Newman RJ, O'Meara GF, and Whiting PJ, et al. (2007) Differential contribution of GABA(A) receptor subtypes to the anticonvulsant efficacy of benzodiazepine site ligands. J Psychopharmacol 21:384-391.

Gallos G, Yim P, Chang S, Zhang Y, Xu D, Cook JM, Gerthoffer WT, and Emala CW, Sr (2012) Targeting the restricted $\alpha$-subunit repertoire of airway smooth muscle GABAA receptors augments airway smooth muscle relaxation. Am J Physiol Lung Cell Mol Physiol 302:L248-L256.

Gallos G, Yocum GT, Siviski ME, Yim PD, Fu XW, Poe MM, Cook JM, Harrison N, Perez-Zoghbi J, and Emala CW, Sr (2015) Selective targeting of the $\alpha 5$-subunit of GABAA receptors relaxes airway smooth muscle and inhibits cellular calcium handling. Am J Physiol Lung Cell Mol Physiol 308:L931-L942.

Groves JO, Guscott MR, Hallett DJ, Rosahl TW, Pike A, Davies A, Wafford KA and Reynolds DS (2006) The role of GABAbeta2 subunit-containing receptors in mediating the anticonvulsant and sedative effects of loreclezole. Eur J Neurosci 24 167-174.

Hintersteiner J, Haider M, Luger D, Schwarzer C, Reznicek G, Jäger W, Khom S, Mihovilovic MD, and Hering S (2014) Esters of valerenic acid as potential prodrugs. Eur J Pharmacol 735:123-131.

Hörtnagl H, Tasan RO, Wieselthaler A, Kirchmair E, Sieghart W, and Sperk G (2013) Patterns of mRNA and protein expression for 12 GABAA receptor subunits in the mouse brain. Neuroscience 236:345-372.

Jung HY, Yoo DY, Nam SM, Kim JW, Choi JH, Yoo M, Lee S, Yoon YS, and Hwang IK (2015) Valerenic Acid Protects Against Physical and Psychological Stress by Reducing the Turnover of Serotonin and Norepinephrine in Mouse HippocampusAmygdala Region. J Med Food 18:1333-1339.

Jurd R, Arras M, Lambert S, Drexler B, Siegwart R, Crestani F, Zaugg M, Vogt KE Ledermann B, and Antkowiak B, et al. (2003) General anesthetic actions in vivo strongly attenuated by a point mutation in the GABA(A) receptor beta3 subunit. FASEB J 17:250-252.

Khom S, Baburin I, Timin EN, Hohaus A, Sieghart W, and Hering S (2006) Pharmacological properties of GABAA receptors containing gamma1 subunits. Mol Pharmacol 69:640-649.

Khom S, Baburin I, Timin E, Hohaus A, Trauner G, Kopp B, and Hering S (2007) Valerenic acid potentiates and inhibits GABA(A) receptors: molecular mechanism and subunit specificity. Neuropharmacology 53:178-187.

Khom S, Strommer B, Ramharter J, Schwarz T, Schwarzer C, Erker T, Ecker GF, Mulzer J, and Hering S (2010) Valerenic acid derivatives as novel subunit-selective GABAA receptor ligands - in vitro and in vivo characterization. $B r . J$ Pharmacol 161:65-78.

Kopp S, Baur R, Sigel E, Möhler H, and Altmann K-H (2010) Highly potent modulation of GABA(A) receptors by valerenic acid derivatives. ChemMedChem 5:678-681.

Krishek BJ, Moss SJ, and Smart TG (1996) Homomeric beta 1 gamma-aminobutyric acid A receptor-ion channels: evaluation of pharmacological and physiological properties. Mol Pharmacol 49:494-504.
Löw K, Crestani F, Keist R, Benke D, Brünig I, Benson JA, Fritschy JM, Rülicke T, Bluethmann H, and Möhler H, et al. (2000) Molecular and neuronal substrate for the selective attenuation of anxiety. Science 290:131-134.

Luger D, Poli G, Wieder M, Stadler M, Ke S, Ernst M, Hohaus A, Linder T, Seidel T, and Langer T, et al. (2015) Identification of the putative binding pocket of valerenic acid on GABAA receptors using docking studies and site-directed mutagenesis. $\mathrm{Br}$ $J$ Pharmacol 172:5403-5413.

Methfessel C, Witzemann V, Takahashi T, Mishina M, Numa S, and Sakmann B (1986) Patch clamp measurements on Xenopus laevis oocytes: currents through endogenous channels and implanted acetylcholine receptor and sodium channels. Pflugers Arch 407:577-588.

Miller PS and Aricescu AR (2014) Crystal structure of a human GABAA receptor. Nature 512:270-275

Miralles CP, Li M, Mehta AK, Khan ZU, and De Blas AL (1999) Immunocytochemical localization of the beta(3) subunit of the gamma-aminobutyric acid(A) receptor in the rat brain. $J$ Comp Neurol 413:535-548.

Möhler H, Crestani F, and Rudolph U (2001) GABA(A)-receptor subtypes: a new pharmacology. Curr Opin Pharmacol 1:22-25.

Olsen RW and Sieghart W (2008) International Union of Pharmacology. LXX. Subtypes of gamma-aminobutyric acid(A) receptors: classification on the basis of subunit composition, pharmacology, and function. Update. Pharmacol Rev 60:243-260.

Pirker S, Schwarzer C, Wieselthaler A, Sieghart W, and Sperk G (2000) GABA(A) receptors: immunocytochemical distribution of 13 subunits in the adult rat brain. Neuroscience 101:815-850.

Reynolds DS, Rosahl TW, Cirone J, O'Meara GF, Haythornthwaite A, Newman RJ, Myers J, Sur C, Howell O, and Rutter AR, et al. (2003) Sedation and anesthesia mediated by distinct GABA(A) receptor isoforms. J Neurosci 23:8608-8617.

Rudolph U, Crestani F, Benke D, Brünig I, Benson JA, Fritschy JM, Martin JR, Bluethmann H, and Möhler H (1999) Benzodiazepine actions mediated by specific gamma-aminobutyric acid(A) receptor subtypes. Nature 401:796-800.

Rudolph U, Crestani F, and Möhler H (2001) GABA(A) receptor subtypes: dissecting their pharmacological functions. Trends Pharmacol Sci 22:188-194.

Rudolph U and Knoflach F (2011) Beyond classical benzodiazepines: novel therapeutic potential of GABAA receptor subtypes. Nat Rev Drug Discov 10:685-697.

Rudolph U and Möhler H (2014) GABAA receptor subtypes: Therapeutic potential in Down syndrome, affective disorders, schizophrenia, and autism. Annu Rev Pharmacol Toxicol 54:483-507.

Sampath C, Haug K, Thanei S, Hamburger M, Derendorf H, Frye R, and Butterweck $\mathrm{V}$ (2012) Pharmacokinetics of valerenic acid in rats after intravenous and oral administrations. Planta Med 78:575-581.

Schwartzkroin PA (1994) Role of the hippocampus in epilepsy. Hippocampus 4 239-242.

Schwarzer C, Berresheim U, Pirker S, Wieselthaler A, Fuchs K, Sieghart W, and Sperk G (2001) Distribution of the major gamma-aminobutyric acid(A) receptor subunits in the basal ganglia and associated limbic brain areas of the adult rat. J Comp Neurol 433:526-549.

Sigel E and Steinmann ME (2012) Structure, function, and modulation of GABA(A) receptors. J Biol Chem 287:40224-40231.

Simon J, Wakimoto H, Fujita N, Lalande M, and Barnard EA (2004) Analysis of the set of GABA(A) receptor genes in the human genome. J Biol Chem 279 $41422-41435$.

Sperk G, Schwarzer C, Tsunashima K, Fuchs K, and Sieghart W (1997) GABA(A) receptor subunits in the rat hippocampus I: immunocytochemical distribution of 13 subunits. Neuroscience 80:987-1000.

Zeller A, Arras M, Lazaris A, Jurd R, and Rudolph U (2005) Distinct molecular targets for the central respiratory and cardiac actions of the general anesthetics etomidate and propofol. FASEB J 19:1677-1679.

Address correspondence to: Dr. Sophia Khom, Department of Pharmacology and Toxicology, University of Vienna, Althanstrasse 14, A-1090 Vienna E-mail: sophia.khom@univie.ac.at; or Dr. Mag. Christoph Schwarzer Department of Pharmacology, Medical University of Innsbruck Peter-Mayr-Str. 1a, A-6020 Innsbruck. Email: schwarzer.christoph@i-med.ac.at 